\title{
INVADIR, ACONSELHAR E GOVERNAR... A CIDADE DA AMÉRICA LATINA*
}

\author{
Etienne Henry e Céline Sachs-Jeantet
}

\author{
"Quiseram dissipar esses grupos, \\ quiseram abafar sens gritos $e$, \\ como acontece nesses casos, \\ os grupos se multiplicaram \\ e os gritos redobraram".
}

(Vinte anos depois, Alexandre Dumas, 1845).

Hoje chega-se facilmente à cidade: tornou-se uma passagem indispensável em nossas sociedades. No entanto, há regiões onde se deve produzir a cidade, antes mesmo de transpor seus muros, isso no sentido mais físico de um ato fundador, como o ato metafórico da inovação de realidades sociais. Executam-se, então, práticas de trangressão e de inovação, onde se combinam a ação e o projeto. Tal relação entre o neo-citadino e as idéias que o movem diz respeito tanto à visão quanto ao olhar, tanto à passagem quanto

\footnotetext{
- Texto publicado originalmente na revista Social Science Information sur les sciences sociales, Sage, London/Newbury Park/New Delhi, n" 32, 2/93, p. 303-361, sob o título "Envahir, conseiller et gouverner... la ville d'Amérique Latine". O texto original apresenta um longo levantamento bibliográfico do qual a presente edição inclui apenas a bibliografia referente ao texto. (NDE)
} 
ao passante, tanto ao urbanizado quanto ao urbanizador. Assim, o discurso sobre a cidade que se vem enunciando na América Latina, há duas décadas, revela um modo sui generis de apreensão dos fenômenos urbanos. Para compreender o motor dessa ação, a metonímia se impõe, não somente como procedimento literário de exposição, mas também em diversos níveis de elucidação do conteúdo da relação causal, analógica, formal ou ainda referencial, entre os conceitos e objetivos assim relacionados. Impõe-se, finalmente, ler a pesquisa urbana latino-americana como um romance de capa e espada, como nos incita a frase citada em epígrafe, esperando aí achar um desfecho'

\section{Três mosqueteiros ou um contingente de pesquisadores?}

Vinte anos de pesquisa urbana na América Latina: uma produção autóctone que se abre também para o exterior, numa estreita relação de cumplicidade e alteridade. O objetivo comum, a cidade, é extremamente fascinante ${ }^{2}$, mesmo se às vezes bastante dramático, se se acredita nas manchetes operadas pela nossa mídia: hordas de crianças, semeando o crime na decadente Rio de Janeiro, bombas em todas as ruelas iluminadas das favelas limenhas, ou narcotraficantes corrompendo a miséria colombiana, às custas

\footnotetext{
${ }^{1}$ Este artigo é uma versāo reduzida e revista de um relatório dos autores: Invadir, aconselhar e governar. Vinte anos de pesquisa urbana latino-americana. INRETS/DRI-MELTE, Paris, 1991, 120 p. Relatório este que expunha nossa observação participante no seminário de Quito (7-11 de setembro 1987): La investigación urbana en America Latina. Caminos percorridos y por recorrer. E é também o relatório de uma série de entrevistas complementares. Nossa escuta foi igualmente a de cúmplices participantes dessa produção. Assim, nossa leitura das elaborações em questão é filtrada por nossa própria imersão transoceânica. Além dos numerosos colegas latino-americanos que acompanham este trabalho e aos quais agradecemos calorosamente, uma leitura atenta deste texto por Henri Coing, Michel Marié, Alain Maurice, Edmond Préteceille, Anne Quérien e Christian Topalov permitiu-nos corrigir algumas falhas.

${ }^{2}$ Assim, depois de uma longa temporada no Brasil, Fernand Braudel (1979, p. 343) dizia: "confesso estar fascinado pela história destas cidades americanas que crescem antes dos campos, ou pelo menos ao mesmo tempo que eles" (sublinhado pelo autor).
}

Rua, Campinas, 2:9-61, 1996 
de nossos vícios... ${ }^{3}$ Para decifrar o enigma dessa realidade-ficção, seria conveniente começar a trilogia pelo primeiro volume (Os três mosqueteiros, Dumas, 1844). Mas esse primeiro volume não permite ainda uma releitura ${ }^{4}$ que pode, no entanto, iniciar-se no segundo tomo da ação narrada. Remontando a vinte anos atrás, o padre Lebret ${ }^{5}$ talvez nos aparecesse sob os signos de d'Artagnan e Regis Debret ${ }^{6}$, sob os de Aramis; quanto a Athos e Porthos, seus traços se desvendam nas páginas escritas pela geração atual dos pesquisadores da cidade. O contingente dos pensadores da cidade latino-americana é algumas centenas de vezes mais numeroso que a brigada de Dumas e, tal como esta, vivem a mesma epopéia que faz com que se encontrem, de um episódio a outro, assegurando uma certa permanência trans-geradora entre os três registros: o da prática, o do saber e o do poder.

\footnotetext{
3 Será que, segundo uma racionalizada "mecânica dos sonhos", o "sonho de uma outra ordem", oposto à simples "subordinação", sairia vitorioso na "dupla vida que caracteriza as cidades [latino] americanas desde sua origem", dispostas segundo um princípio indiscutível? "A ordem deve ser estabelecida antes que a cidade exista, para prevenir qualquer desordem futura, o que remete à própria virtude dos signos de permanecer inalteráveis no tempo e dirigir a turbulenta vida das coisas em quadros rígidos", para retomar os termos de Angel Rama (1984). Precisemos que sueño tanto pode ser traduzido por songe* como por rêve*, logo também por pesadelo... pelo menos no espírito do grande ordenador das coisas deste mundo. (* mantivemos estes termos no original, porque o português usa um só termo, sonho, para traduzir songe e rêve. N. do T.).

${ }^{4}$ Releitura concernente, em primeiro lugar, às referências latino-americanas de base, apresentadas adiante, seguindo os temas de nosso recorte.

5 O fundador de Economie \& Humanisme, depois de ter criado seu método de enquete social, a serviço da Igreja, observando os pescadores a partir da sociologia de La Play, viajou muito nos anos 50 pela Venezuela, Brasil, Chile e Colombia, entrando nas favelas para recolher elementos de planejamento urbano. Durante muito tempo fez escola, embora as geraçōes recentes possam ter esquecido seu nome.

${ }^{6}$ Essa é, pelo menos, a convicção que nos transmitia Enzo Faletto, por ocasião de uma entrevista sobre as marcas significativas e influências francesas, estejam elas esquecidas ou presentes na consciência dos herdeiros atuais da produção de conhecimento. Os posicionamentos políticos tiveram importante papel nas diferenciações teóricas, mesmo no interior de uma mesma corrente de pensamento.
}

Rua, Campinas, 2:9-61, 1996 


\subsection{Discursos latinos sobre a cidade da América}

A história desse continente, que é também o berço da Europa, se era pela conquista que esta se constituía, há cinco séculos ${ }^{7}$, está semeada de equívocos: traz o nome de um navegador, recompensado erroneamente, assim, por um professor primário do Vosges; seus habitantes são os índios que Cristóvão Colombo pensou ter encontrado (por uma abjurgação religiosa que lhe sobreviveu por muito tempo) e suas cidades se parecem todas à explosiva Macondo onde terminam sempre as epopéias do coronel Aureliano Buendía $^{8}$. Mas tais denominações são também fundadoras de realidades, atraindo e espantando num mesmo movimento de olhar, afastando-se na diferença'. Mesmo abusando-se da linguagem, essas denominações são latinas, logo, próximas de nós, e a cidade latino-americana se propõe como um objeto próprio para o historiador (Morse, 1971) e para o homem de letras (Romero, 1976), tanto quanto para as ciências humanas (Hardoy, 1975).

Assim, no decurso das duas últimas décadas, a pesquisa urbana expandiu-se em vinte países dessa região ${ }^{10}$. No Chile e na Argentina (e em menor escala, no México e no

\footnotetext{
${ }^{7}$ E, segundo Stein, retomado por Rama (1984), "a Espanha já estava em decadência no momento do descobrimento da América Latina, e, se Madri estava na periferia da periferia... Mais que uma fabulosa conquista, foi o inegável triunfo das cidades sobre um imenso território desconhecido, reiterando a concepção grega que opunha a polis civilizada à barbárie dos não urbanizados".

8 "O mundo era tão recente que muitas coisas careciam de nomes e, para mencioná-las, se precisava apontar com o dedo (...) Em sua juventude, José Arcádio Buendía e seus homens, com mulheres, crianças, animais e todo tipo de artigos domésticos, tinham atravessado a serra, à procura de uma saída para o mar; ao cabo de vinte e seis meses, tinham abandonado o empreendimento e fundado Macondo, para não terem que tomar o caminho de volta. Na realidade, essa estrada não interessava, uma vez que só podia conduzi-lo ao passado." (Garcia Marquez).

") "O olho não vê coisas, mas imagens de coisas que significam outras coisas. Ele percorre os caminhos como páginas escritas: a cidade diz tudo o que você deve pensar e faz você repetir seus discursos" (Calvino, 1972:22).

${ }^{10}$ A leitura dos balanços geográficos sobre cada um dos países (Carrión, 1990) confirma a idéia de um quadro comum e de movimentos de pensamento similares, para além das diferenças de contextos e de
} 
Brasil), constituíram-se os seus mais antigos núcleos, junto a instituições universitárias locais e a organizações internacionais (nessa ordem: Torcuato di Tella, Ford, Cepal, Siap, Clacso $)^{11}$ cujas pesquisas se orientam para a meta-teoria transmitida de geração em geração (Coraggio, 1990, Henry, 1984, Henry et Sachs, 1991, Jaramillo,1990. Kowarick, 1992, ou Yujnovsky, 1983).

Mas, no fundo do continente, os países do Cone Sul foram submetidos a mudanças políticas brutais, que alteraram profudamente a dinâmica da pesquisa, ela própria politizada, e que provocaram descontinuidades nas trajetórias locais. Os países andinos alimentaram, também, com uma certa defasagem, uma pesquisa mais marcada pelas características próprias do processo de urbanização dessa região (as favelas, o crescimento tardio...). No Brasil, os estudos urbanos, embora mais antigos, proliferaram com o milagre econômico, sob o regime militar e com a poderosa intervenção do Estado (Valladares, 1989). No México, a pesquisa permaneceu essencialmente universitária, em estreita relação, inclusive contraditória, com a administração (Garza et Aguilar, 1989). Na América Central, a pesquisa está menos consolidada, porque a problemática urbana não se impõe com a mesma acuidade, e a pequena dimensão dos países justifica uma preocupação mais regional que urbana (Lungo, 1989).

A diversidade remete à unidade: as realidades são suficientemente variadas de um extremo ao outro do continente - como aliás de um ponto a outro de um país, até mesmo de uma zona a outra da cidade - para que se possa discutir a pertinência de um denominador comum. Ora, a pesquisa urbana latino-americana afirma-se como a expressão de uma realidade que transcende as particularidades e aí está provavelmente

\footnotetext{
conjunturas. Esse quadro comum não impede que haja nuanças importantes, certas evoluções locais sendo mais voltadas para o político, o social, o econômico ou o cultural.

"A Cepal da ONU (Comissão Econômica para América Latina), o PREALC do BID (Programa de Emprego para a América Latina e o Caribe), a Foundation Ford e o Population Council, o ILPES, dos planejadores (Instituto Latino-americano de Planejamento Econômico e Social), o CLACSO (Conselho Latino-Americano de Ciências Sociais) cuja comissão urbana festejava, recentemente, seus trinta anos, a SIAPS dos arquitetos (Sociedade Interamericana de Planejamento), a FLACSO das ciências sociais (Faculdade Latino-Americana de Ciências Sociais), etc
}

Rua, Campinas, 2:9-61, 1996 
uma das principais razões de sua perenidade. Poder-se-ia estender essa asserção às Ciências Socias em geral, que se desenvolvem no ritmo dos atores sociais ${ }^{12}$.

Em que uma determida cidade diferiria das realidades conhecidas em outros lugares? No fato de que toda cidade está circunscrita a uma sociedade. Mas pode-se, então, falar em sociedade latino-americana (segundo Galeano, 1971, contra Niedergang, 1972), portadora de formas urbanas particulares ${ }^{13}$ ? A análise dessa sociedade questionaria os princípios que alguns apresentam para construir o urbano e, outros, para simplesmente ler aí fatos sociais não circunscritos a um tal quadro. A cidade latinoamericana seria assim tão original a ponto de merecer especulações sobre vinte anos de elocubrações particulares? Voltando ao campo urbano, dificilmente se pode negar a existência de um discurso científico particular, mesmo que ele não seja inteiramente autônomo. E a relação entre este discurso e aquela realidade interessa-nos sobremaneira, quando nada por situar-se aquém da ação social e do político, imiscuindo-se entre os dois por suas aspirações intervencionistas. Se a legitimidade científica do recorte de um campo urbano pôde ser negada nas sociedades "pós-industriais" (sobretudo por Manuel

\footnotetext{
12 "[Minha reflexão] parte da hipótese de que existe um modo latino-americano de desenvolvimento, isto é, uma combinação, própria desse continente, de racionalismo econômico e de mobilização política e social... A América Latina é um continente de atores sem ação... Mesmo quando os atores são fracos, ausentes ou desarticulados, é sempre em termos de atores e de capacidade de ação que se colocam os problemas da América Latina. É nisso que seu estudo pode nos ajudar a redescobrir que entre a lógica implacável do controle social e a liberdade selvagem do lucro, o essencial da vida social é constituído de relaçōes entre os atores e que somente a união de suas esperanças e de seus combates pode produzir o que denominamos desenvolvimento" (Touraine, 1988:13,469, 475, sublinhado pelo autor).

13 "Assim, o sociólogo que estuda o Brasil não sabe qual sistema de conceitos utilizar. Nenhuma das noções aprendidas nos países europeus ou norte-americanos valem mais. O velho mistura-se ao novo. As épocas históricas se misturam umas nas outras. As mesmas palavras como 'classe social' ou 'dialética histórica' não têm significado igual, não recobrem as mesmas realidades concretas. Seria necessário, ao invés de conceitos rígidos, descobrir noções de certa forma líquidas, capazes de descrever fenômenos de fusão, ebulição, interpenetração, que se amoldariam a uma realidade viva, em perpétua transformação. O sociólogo que quiser estudar o Brasil deve se fazer poeta" (Bastide, 1957:15).
}

Rua, Campinas, 2:9-61, 1996 
Castells em sua diatribe com Henri Lefèbvre nos anos 1970) ${ }^{14}$, poderia ser de uma outra maneira no caso da América Latina (Pradilla, 1984)?

A reflexão urbana sobre esse continente apresenta uma especificidade tal, que é possível esboçar seu perfil próprio. Ela revela tanto uma realidade diferente, quanto é diferente sua maneira de abordá-la. O debate latino-americano revela um modo cognitivo próprio e traz elementos locais de resposta a desafios, não só urbanos como também econômicos e sócio-políticos. Esse debate, partindo de modos de abordagem específicos, apropriou-se dos instrumentos de análise forjados em outros contextos (do culturalismo americano ao estruturalismo francês, veiculado através das propostas do que se denominou "a nova escola marxista"). Esses instrumentos, considerados literalmente, não eram, na verdade, adaptados às especificidades locais e foi preciso remodelá-los. Viramse, assim, nações atravessarem várias vezes o Altântico ou o canal do Panamá, num movimento de boomerang teórico, tão mortífero às vezes aqui, quanto lá.

Acredita-se estar um pouco afastado do modo científico de abordagem da realidade; e, no entano, existe aí produção de crescimento ${ }^{15}$ (assim, o centro Ciudad conseguiu repertoriar centenas de títulos produzidos nos últimos vinte anos). Temos muitas vezes a impressão de estarmos mais na epopéia, presos no turbilhão da ação e nas suas inter-relações com a ciência, o que significa, pois, que encontramos divergências e contradições, tanto no corpus de saberes quanto nos savoir-faire operacionais ou na inteligência oriunda das práticas e, naturalmente, entre as três esferas evocadas em nosso título.

\footnotetext{
${ }^{14}$ Entre os numerosos participantes desse questionamento, ver, por exemplo, a reconstituição do debate epistemológico que Christian Topalov propõe em "Faire l'histoire de la recherche urbaine: l'expérience française depuis 1965" (Coraggio, 1990). Não é por acaso que esse texto, posteriormente difundido em outros lugares, tenha sido escrito para latino-americanos.

${ }^{15}$ Em dois registros diferentes, ver como Pierre Bourdieu sintetiza o discurso científico de uma antropologia reflexiva em Réponses (com Loïc Wacquant, 1992), e como Jürgen Habermas opõe a teoria crítica da sociedade à simples produção de conhecimentos, em Connaissance et Intérêt (1976).
}

Rua, Campinas, 2:9-61. 1996 


\section{2. Personagens em busca de objeto urbano}

Entre os invasores de terra que entram na cidade latino-americana, há muitas décadas, distinguem-se líderes que tentam achar soluções para problemas imediatos e sucessivos de seus grupos (terreno, moradia, equipamentos e infra-estruturas comunitárias: água, eletricidade, educação, transportes, saúde, alimentação, títulos de propriedade, até mesmo emprego). Há algumas décadas, eles são acompanhados por conselheiros que, antes, preferiam colocar sua competência a serviço das oligarquias e dos poderes estabelecidos (Geisse, 1968, Ortíz, 1989). Ora, eis que nos últimos anos esses dirigentes e/ou seus mentores se vêem, eventualmente, alçados aos postos de governo da cidade (em Lima, São Paulo, Quito, Colômbia ou em diversas cidades do México etc). Esse resultado, afinal bastante banal, de uma trajetória movimentada, intervém num contexto particular: o da consolidação de processos de urbanização grandiosos, como também o de desenvolvimento em crise (Schteingart, 1989). Além de sua perenidade, espantosa, face aos sobressaltos das escolas anglo-saxônicas ou francesas, duas características maiores marcam a pesquisa urbana latino-americana: se por um lado ela é muito sensível às conjunturas, por outro permanece constantemente em busca de princípios unificadores e estáveis.

Primeiramente, pois, essa pesquisa é conjuntural, em incessante interação com as mudanças econômicas, urbanas, sociais, políticas e institucionais de seu continente de referência. Procede assim por aproximação interativa das realidades ${ }^{16}$, realidades naturalmente cambiáveis, mas que guardam o mesmo poder de interpelação; realidades que a pesquisa redescobre constantemente, partindo de novos temas, que se excluem uns aos outros. Nesse contexto, a tensão entre teoria e prática é particularmente forte, mesmo no momento em que se generalizam as condutas de pesquisa-ação (sobretudo as propagadas pelas organizações não governamentais) que avançam mais rapidamente do

\footnotetext{
${ }^{16}$ Considerando como já conhecidos os dados de base (ver bibliografia adiante), não será feita aqui nenhuma apresentação descritiva das realidades urbanas latino-americanas, e nem de sua evolução. A representação e a medida das realidades estão, pois, implícitas neste texto, como o estão, muitas vezes, na pesquisa urbana latino-americana, enquanto sua construção está no centro do debate.
}

Rua, Campinas, 2:9-61, 1996 
que as abordagens mais acadêmicas e teóricas dos problemas. Tais condutas situam-se na ótica da demanda social, cujos pesquisadores se colocariam como mediadores em relação a instituições políticas, a instâncias estatais e a organismos internacionais.

Uma segunda particularidade dessa pesquisa é que ela está permanentemente a procura de um "paradigma latino-americano" que, segundo uma intenção já latente nas produções do fim dos anos 60 , permitiria afirmar sua unidade e especificidade, levando em conta ao mesmo tempo a diversidade das realidades e dos processos. É o caso, por exemplo, de uma análise da "heterogeneidade estrutural", proposta para caracterizar a neo-urbanização no seu início, e que é reivindicada como uma característica social maior (Quijano, 1968 e 1989). Trata-se de um ou de vários paradigmas? Ainda mais curiosas que a seqüência ação/direção, passarelas asseguram o trânsito entre essas três áreas. As influências mútuas são fortes, na designação dos objetos de pesquisa e de intervenção e no seu tratamento. Mas as passagens são também feitas por pessoas que não se encontram sucessivamente, e às vezes simultaneamente, nesses três registros.

O discurso sobre a cidade latino-americana é, pois, original, seja graças aos homens que o elaboram, abrangendo vários planos de prática e de conhecimento, em condições de grande penúria (comparáveis, sob certos aspectos, às que experimentam os invasores de terrenos e outros habitantes dos bairros populares), seja graças ao campo que se recorta, face a uma realidade violenta, maciça e enigmática. Esse discurso é feito por um cavaleiro bem firme em seu estribo: à esquerda, a prática coletiva e, à direita, a gestão (ou o inverso), que delimitam sua área de conhecimento, apresentando então, um caráter fracionado e de construção inacabada.Há um momento em que o cavaleiro sente necessidade de pôr os pés na terra, para se situar, observando o caminho percorrido, ou para considerar o espaço que ele se delimitou, ao longo de uma corrida raramente retilínea. É a hora de fazer o balanço ${ }^{17}$. O conjunto de questões, às quais remete a análise

\footnotetext{
${ }^{17} \mathrm{Na}$ França também a sociologia urbana, maltratada por tantos questionamentos, interroga-se sobre sua consciência e sobre sua legitimidade; do mesmo modo, ela examina produções de outros países, sobretudo do Terceiro Mundo. Ver sobretudo a leitura discutida de Amiot (1986) e as interrogações de uma comunidade francesa perplexa depois de vinte anos de árduos debates (LARES, 1991); ver também os Etats de la question, produzidos pela Inteurba/Tiers Monde.
} 
dos processos chamados urbanos, encontraria resposta na própria cidade (daí a pesquisa do paradigma perdido) ou em outros princípios explicativos (o processo de desenvolvimento, o histórico, o social, o político, que não podem, entretanto, ignorar a cidade para serem elaborados)? Difícil questão, que permanece em suspenso, faz agora mais de vinte anos. Essa questão não é, aliás, própria da América Latina, mesmo se a urbanização nela revestisse formas particulares e, conseqüentemente, se a maneira de colocá-la se tornasse própria. Ela volta com intensidade na França de hoje, mas não há mais muita gente que se disponha a ser o servidor de Richelieu, enquanto lá, no contingente de Maquiavel, alguns chegam a se tornar Príncipes.

\section{Vinte anos depois ou um campo perene}

O piscar de olhos suscitado pelo subtítulo desse artigo é o de um romance francês que não tem muita coisa a ver com a pesquisa urbana apresentada a seguir: Vinte anos depois não aparece na bibliografia, mesmo se a obra está presente ainda nas telas televisivas da juventude latino-americana. Por que não se deixar embalar por aventuras? Estas começavam, no segundo tomo da famosa trilogia de Dumas, num gabinete escuro e em desordem onde, de manhãzinha, via-se de costas, sentado à sua escrivaninha, um estranho personagem, enquanto na rua ouviam-se os últimos ruídos do que parecia ter sido um tumulto popular... A metonímia não é imprópria. O que escrevia ele e o que se escrevia há vinte anos, diante do que se considerava um tumulto, pelo menos por aqueles que o qualificavam de "urbanização selvagem" (metáfora perturbadora, mesmo na pena de uma inteligentzia moderna)? O que se escreveu posteriormente, num registro mais culto?

Extrapolando, a partir de representações contingentes, pode-se detectar cinco movimentos de pensamento, escandindo a tragetória dessa pesquisa e sustentando a taxinomia dos dados empíricos e dos fatos sociais, qua abrem pistas de interpretação. $\mathrm{O}$ primeiro movimento institui o teatro da ação: partindo-se dos processos globais de urbanização dessas sociedades, apreende-se o espaço cênico. Do processo global aos atores. O segundo instala o cenário principal da obra: da sua manifestação 
impressionante, a assim chamada favela (em francês bidonville), à sua retórica, a da marginalidade. Tomando a contra-partida dessa proposta, o terceiro movimento de pensamento coloca lado a lado os partidários de uma má controvérsia, para que abram o caminho da ação coletiva: da marginalidade aos movimentos sociais. Por sua vez denunciada, essa concepção levará posteriormente os pensadores a se apropriarem das chaves da cidade, quando eles virem na gestão delas um nó de condensação dos problemas urbanos. Depois, a crise os levará aos processos estruturais e a uma marginalidade repensada como o informal. Esse pensamento que se fecha sobre si mesmo de maneira admirável, longe de ser cego às perturbações da realidade urbana em vinte anos de evolução, resultará numa noção em plena via de descoberta: a cidadania. Os cinco movimentos dessa trajetória evocam tanto a extraordinária consciência da identidade da comunidade dos pesquisadores latino-americanos, devotados ao urbano, quanto à consciência de uma certa idéia da cidade, para além dos debates teóricos e do tratamento dos conceitos, e a consistência de uma utopia.

\section{1. Do processo global aos atores}

Antes de se introduzirem no castelo da rainha, nossos quatro mosqueteiros contornam as muralhas. Vamos, pois, segui-los, num primeiro reconhecimento do campo da pesquisa urbana latino-americana, para poder saber, posteriormente, onde se põem os pés quando se abre uma porta e se examina um tema particular. Na trajetória da pesquisa urbana das duas últimas décadas, constata-se, de um lado, o aparecimento de certos objetos consensuais, e de outro, divergências de interpretação que deram lugar a importantes debates. Essa relação entre uma realidade empírica de grande visibilidade social e conceituações, procedentes de diferentes disciplinas e de diversas correntes de pensamento, dá uma idéia geral da evolução temática, sem que por isso se chegue à construção de uma problemática coerente e articulada. Os balanços locais revelam um paralelismo na evolução das abordagens das realidades urbanas dos diferentes países latino-americanos. As especificidades locais levam, entretanto, a uma diacronia do pensamento. As diferenças sensíveis de ritmo e de aprofundamento nas preocupações e 
nas elaborações produzidas de um país a outro se devem tanto às características próprias dos processos de urbanização, quanto ao clima intelectual e às conjunturas políticas conhecidas por cada país. É possível ver a política urbana de cada país. É possível ver a pesquisa urbana latino-americana se constituir em um campo específico das ciências sociais, em torno dos conflitos pertinentes no plano social e político: integração/submissão, controle/autonomia, cidadania/exclusão. Os temas de pesquisa se transformam segundo as conjunturas, e uma mesma realidade social pode ser batizada diferentemente de uma época a outra. O ângulo sob o qual essa realidade é vista permite conceituar aspectos mais ou menos aclarados ou ocultados, segundo os movimentos de pensamento que garantem a passagem de um tema a outro.

Na pesquisa em ciências sociais, a cidade adquire um direito de cidadania no período eufórico da industrialização pela substituição das importações: as novas realidades urbanas se acham no extremo oposto da opção por um desenvolvimento modernizante e integrador (Germani, 1962). A pesquisa deve fornecer os elementos de compreensão da realidade social para remediar as principais patologias das cidades (DESAL, 1960-66). Esse período é também o do apogeu do populismo latino-americano, quando os fenômenos econômicos e políticos se reforçavam mutuamente: a cidade se apresentava como uma das principais esferas de sua interferência (Beyer, 1967).

Há aí matéria para reflexão. O processo de industrialização tão desejado requer um mercado, mas esse se limita às camadas médias urbanas. Esse processo cria também uma classe operária, preferencialmente localizada nas cidades, mas que, nessa época, só se beneficia marginalmente do produto social. Por que, então, se institui a cidade, e cidade não apenas reduzida a seu centro, mas abrangendo toda uma periferia até então considerada como semi-rural, clandestina ou perigosa? Importantes discussões vão realizar-se em série, questionando a funcionalidade dessas populações em relação aos esquemas dominantes do desenvolvimento (CEPAL, 1960-70).

Observa-se, entretanto, que são os governantes que instituem a cidade, nomeiamna e a delimitam, como no tempo dos espanhóis... ou de Richelieu. Eles vão mesmo mais longe, já que as políticas populistas instituem uma relação entre um Estado fraco e um povo que não o é menos, para que eles se confortem mutuamente (Germani, 1072). 
Posteriormente, a pesquisa se debruçará sobre essa relação social sui generis (Instituto Torcuato di Tella, 1965-70).

Em seguida, essas políticas de modernização se esgotam. O urbano torna-se um terreno de confrontação entre estratégias políticas fortemente diferenciadas (opções populistas, modernizantes ou revolucionárias, ou autoritarismo militar) (Weffort, 1968). A cidade é um lugar privilegiado de confrontação entre o poder estatal e a sociedade civil - como se as fronteiras entre essas duas esferas estivessem claramente delimitadas na América Latina. A pesquisa não hesita, então, em exagerar, para encontrar as interrelações de atores - aliás ambíguas - traços de confronto de classes (CIDU, 1967-73),

A crise econômica varre qualquer visão utópica de uma mudança social que se apoiaria na modernização ou na transformação das dinâmicas urbanas: as solidariedades da ação coletiva são substituídas por condutas muito mais defensivas dos atores sociais e dos indivíduos (Lewis, 1988). Enfim, a relativa democratização formal dos aparelhos estatais faz aparecer jogadas mais pragmáticas, retomando a cidade como pretexto ou como referência.

Em toda essa evolução, a pesquisa elabora e veicula imagens da cidade, formula estratégias, inspirando-se em realidades e exigências do político. A evolução dessas realidades e dessas exigências constitui o quadro no qual a reflexão evolui de um tema a outro. O movimento do pensamento procede de diagnósticos das realidades urbanas, inicialmente apresentadas como patológicas, até que se detecte vetores positivos de mudança. Foi assim que se partiu do reconhecimento da favela enquanto expressão das deformações da urbanização latino-americana e do subdesenvolvimento, para se formular o paradigma da marginalidade, antes de se desenvolver uma visão mais incisiva e antagônica, a dos movimentos urbanos. Esse último tema, inicialmente portador de uma visão crítica da cidade e das teorias anteriores, tornou-se em seguida o tema da gestão e da participação urbanas; e é novamente a partir de uma visão patológica da crise urbana que se discutem hoje vícios e virtudes da informalidade.

Patologia, favela, remédios são termos tomados ao saber corrente, à linguagem de rua e da imprensa, exprimindo uma preocupação curativa. Esses adjetivos impróprios são constantemente denunciados ou redefinidos. Todos os pesquisadores tiveram como desafio, desde o início de seus trabalhos, libertar-se de tal ótica que obscurece a relação 
com o objeto. Entretanto, o contexto é tão atraente que se tem muitas vezes a impressão que a demanda da pesquisa, segundo uma teleologia terapêutica, formula-se por si mesma; ela é mais imposta ao pesquisador do que formulada por ele. As realidades urbanas estão aí, mas a cidade deve ser (re)feita. Tal exigência explica a ambigüidade de um posicionamento da pesquisa que deve não só partir das pré-noções como delas livrarse, sem nunca chegar a uma construção metódica, liberada das contingências da prática. Há sempre uma relação bidirecional entre a teoria em vigor e as soluções preconizadas. A gênese dos temas mostra bem essa busca, visando uma boa posição de análise.

A reflexão urbana vai do macro ao micro, do processo geral às particularidades concretas; permanece tributária do pensamento sociológico da região; remói temas que se sucedem, se recortam e se entrelaçam; adota pontos de vista alternativos, segundo as teorias de referência e as dinâmicas sociais e políticas: se existe uma noção que permite transformar o recorte empírico da realidade em definição de um campo de análise é, sem dúvida alguma, a noção de movimentos. Esses se superpõem aos processos globais e situam a cidade no coração das relações de atores que fundam a sociedade latinoamericana. Aí talvez esteja a maior originalidade desse objeto, que implica uma posição particular para analisá-lo.

\section{2. Das favelas à marginalidade}

Nossas aventuras prosseguem, pois, no pântano onde os três mosqueteiros se perderam. É de manhãzinha, a estrada foi longa, nem abrigo, nem pousada. Por que não invadir esse terreno, mesmo sendo pantanoso, e aí construir um teto? Parece ser um costume por aqui.

Diante da rapidez e do caráter maciço das migrações provenientes das regiões rurais, a cidade é vista primeiramente como um receptáculo que dificilmente consegue conter as tendências demográficas e absorver a mão de obra pouco qualificada. A 
favela ${ }^{18}$ designa um gênero de habitação popular, produzido por ocupação, legal ou não, improvisada ou progressiva, de terrenos baldios mais freqüentemente públicos que privados, localizado na periferia (mas, às vezes, também, no coração da cidade), manifestação tangível da idéia de um escoadouro, ameaçando o quadro limitado das estruturas urbanas rígidas.

A favela é assim compreendida muito mais como forma urbana, como forma social, do que como forma espacial. Mas ela é, de qualquer forma, uma sociedade de estrangeiros, de migrantes, de homens do campo, de tudo o que é o avesso da cidade, para quem só tem como ponto de referência uma sociedade urbana moderna. Mesmo não sendo talvez total, a favela é um verdadeiro fato social e torna-se um ponto de ancoragem e de legitimação de uma conduta científica. Essa é provavelmente uma das razões pelas quais a pesquisa urbana latino-americana terá tanta dificuldade, posteriormente, em abandonar sua pedra fundadora (assim ficou estigmatizada uma certa "barriadologia").

Até então, as dinâmicas internas tinham permitido conciliar as mutações urbanas com as estruturas espaciais das velhas cidades coloniais. Assim, o problema da habitação das camadas populares era resolvido - ou ocultado - pelos cortiços ${ }^{19}$. O crescimento dos cortiços no inteiror dos perímetros urbanos foi conseqüência do aluguel de antigas moradias burguesas subdivididas e abrigando grandes densidades de população. Essas mutações internas produziam-se no âmbito de um certo respeito das lógicas que dominam o mercado fundiário, a ocupação do solo, o acesso aos circuitos de consumo, etc.

A favela apareceu primeiramente como uma forma urbana em ruptura total com essas lógicas, como uma não-cidade às portas da cidade, e até mesmo já dentro dela, pelo menos fisicamente, mesmo se se discutisse que ela o fosse socialmente. Via-se nela um símbolo do esgotamento de um sistema urbano que perdera sua capacidade interna de regulação. Pensou-se, então, que a formação das favelas questionava as lógicas de acesso à terra, baseadas nos mercados fundiários e imobiliários. A favela era assim apreendida

\footnotetext{
18 "Bidonville", no original, termo aproximativo em francês para esse gênero de habitação; segundo os autores, o termo "bidonville" é criticado, com razão, e recobre realidades diversas. N. do T.

${ }^{19}$ São os cortiços de São Paulo, os conventilhos de Santiago do Chile ou os tug.
} 
como uma irrupção da espontaneidade na cidade, como uma expressão da urbanização espontânea, e era considerada como um câncer.

Essa imagem de uma cidade ameaçada de transbordamento legitimou a aplicação de políticas urbanas sanitárias: as favelas deveriam ser contidas, controladas, e seu crescimento deveria ser interrompido, adotando-se medidas coercitivas. Era a época da erradicação maciça que correspondia a uma palavra de ordem comum a numerosos governos latino-americanos, a de eliminar o cancro dos marginais, que representa um perigo público e um atentado à ordem urbana. Durante muito tempo ignoradas pelas elites dirigentes, as favelas tornavam-se agora incômodas. Subestimando-se a extensão do que elas representavam, os poderes públicos acreditavam-se capazes de executar políticas de evicção total. Mas, tendo sido transposta a etapa do reconhecimento do seu caráter social, tratava-se então de uma guerra contra um inimigo, sob a máscara de organização. A cidade, não suportando a alteridade, quis desfazer-se dela prontamente. A favela, produto das migrações, foi também vista como transbordamento, nas aglomerações, que cresciam de maneira incontrolada, dos problemas sociais provenientes do campo. O controle das oligarquias sobre a sociedade passava pela manutenção de barreiras rígidas entre os espaços urbanos e rurais sob seu domínio. Essas barreiras eram questionadas devido ao desenvolvimento de espaços portadores de vestígios rurais no perímetro ampliado das aglomerações. $\mathrm{O}$ outro da cidade, aquele que não é citadino (logo, cidadão, a língua espanhola confundindo as duas noções no mesmo termo, ciudadano) era - e é ainda, às vezes - por excelência, o homem do campo. Legitimava-se a ação contra a favela pelo desejo da manutenção dessas estruturas de dominação; no plano político, mecanismos de cooptação visavam restabelecer elos privilegiados entre as elites oligárquicas e os neo-urbanos. Passava-se então do saneamento ao higienismo, da erradicação à permissividade, da evicção à tolerância. Os programas públicos de urbanização das favelas, baseadas no reconhecimento da ocupação dos terrenos, negociada explícita ou implicitamente, e no melhoramento pontual de certos elementos do padrão de vida, visavam, na realidade, restabelecer elos entre as elites e os marginais e estabilizar relações privilegiadas entre eles. Era o germe de uma relação dual entre atores, com toda sua ambigüidade. 
Como foi possível pensar que tais ações de coerção e de cooptação pudessem constituir uma defesa contra correntes migratórias de tal amplitude? Alimentada por esses fluxos, a favela, realidade persistente, iria tornar-se um fora-da-cidade, simbolizando então a exclusão, o reverso dos processos de modernização e de industrialização. Essa exclusão tornava esses indígenas urbanos, mas não cidadãos; habitantes, mas não participantes. Será preciso esperar os anos 70 para que tal descodificação seja possível e para que se leia nessa relação entre a cidade e sua periferia fenômenos de poder bastante poderosos, mas reversíveis, evidentemente. Observemos de passagem que uma boa leitura das teses da Escola de Chicago (e não a leitura atrofiada e anatematizada, que se propagava então nas universidades daqui e de lá) tivesse talvez permitido descobrir mais cedo o sentido dessa alteridade.

A visão da cidade latino-americada ficou então fortemente impregnada de uma interpretação dicotômica; contrapôs-se a "cidade legal" à "favela ilegal", a riqueza à pobreza, o dinamismo à passividade, a integração à anomia. Duas séries de agentes se situaram na interface dessa dicotomia cidade/fora da cidade e preconizaram, a partir dessas bases, a reabilitação da favela: certas correntes religiosas e promotores sociais às vezes ligados às frações progressistas da administração pública.

Agentes eclesiásticos questionaram realmente as boas razões das políticas modernizantes que reforçam a exclusão dos grupos sociais mais desfavorecidos; para eles a favela é uma plataforma de onde se pode interpelar as classes dirigentes. Os núcleos da Igreja popular e outras "Comunidades eclesiásticas de base" tiveram papel fundamental na organização da favela. Seus agentes aplicam ainda o método do "ver, julgar e agir", que é uma etapa preliminar à seqüência "invadir, aconselhar e governar". D'Artagnan ainda está aqui.

Promotores sociais e planejadores engajados viram na favela um terreno tangível para pôr em evidência os erros, os desvios e os danos do planejamento urbano, ou os da ausência deles, e usaram isso como argumento para preconizar a modernização administrativa e política. Essa dupla série de condutas pôde se articular num projeto de planejamento urbano alternativo, onde a favela era um terreno privilegiado para pesquisa e para experimentação de fórmulas-piloto de promoção urbana, servindo de referente 
para a formulação de planos de organização das cidades. Tratava-se então, na verdade, de integrar a favela à cidade; mas como proceder, escapando dos fenômenos de poder?

Nessas formulações, a favela era antes de tudo a manifestação de um problema de habitação. Defendiam-se assim propostas explicativas da crise da habitação, ligada, na América Latina, às fraquezas de uma indústria de construção, inteiramente voltada para as necessidades das elites e das camadas remediadas, à inatividade dos poderes públicos e à falta de dinamismo do mercado. No plano fundiário, confirmar-se-ia mais tarde, à medida que se avançava o conhecimento dos diferentes tipos de favela ou de habitação popular, que os processos de invasão eram da mesma ordem.

Para reduzir essa crise, propôs-se aplicar políticas de habitação social. Um dos elementos de modernização do aparelho produtivo, a habitação, dita social, tornou-se rapidamente um mecanismo que permitia ampliar o mercado, promover a ascensão das camadas médias apenas remediadas, sem por isso reduzir o déficit de moradias populares. Costata-se aí o divórcio entre o discurso e uma política que é somente discurso.

Diante das limitações dos poderes públicos, alguns propuseram medidas que valorizavam o potencial da favela e remediavam a fraqueza dos recursos estatais: a autoconstrução, ou a favela vista não mais como um problema, mas como uma solução. Essa proposta não se limitou ao problema da moradia e tornou-se uma filosofia do urbanismo adaptado (Turner, 1963). A moradia auto-produzida pôde ser acompanhada de intervenções pontuais e setoriais em matéria fundiária e de equipamento de infraestruturas e de serviços. Trata-se sempre de negociar uma intervenção mínima do Estado, com a colaboração da população.

As ciências sociais fizeram-se assim o advogado das opções, revalorizando o saber popular, a organização autônoma e a economia dos meios. Ultrapassaram-se, então, as dimensões de micro-experiências para se atingir uma visão estratégica do desenvolvimento das cidades. Instaurava-se um debate entre os defensores de uma visão positiva da auto-construção (Lewis, 1988) e aqueles que não viam nisso senão um mecanismo de auto-exploração, diante das carências do Estado e do mercado capitalista da moradia. Outras pesquisas demonstram também que a apologia do auto- 
desenvolvimento pode ser um pretexto para a penetração de agentes externos, portadores de ideologias reacionárias (Rofrio e Rodriguez, 1970, 1980).

As favelas representaram, assim, um objeto empírico amplamente estudado por pesquisas pontuais, que acentuaram uma ou outra de suas características e questionaram as boas justificativas das imagens sucessivamente veiculadas pela ou para as elites:

Favela, receptáculo das correntes migratórias: percebeu-se rapidamente que essa imagem não correspondia senão parcialmente à realidade. Por um lado, as mobilidades residenciais dos migrantes são mais complexas, e dizem respeito tanto à habitação locativa e aos cortiços dos centros, quanto às novas zonas de povoamento. Por outro lado, as favelas de constituição recente são cada vez mais habitadas por populações nativas da cidade.

Favela, forma ilegal de acesso à terra: se as favelas são a expressão do bloqueio dos mercados fundiários, elas constituem igualmente um mecanismo de desbloqueio, pela habilitação de novos espaços a urbanizar e pela extensão das lógicas fundiárias fora dos perímetros administrativos da cidade.

Favela ou moradia de baixo padrão: elas são vistas como uma manifestação da crise de moradia e a auto-construção é também um remédio para a inadaptação dos setores dominantes de produção de moradia, em relação às necessidades sociais.

Favela, urbanismo fora-das-normas: elas podem ser bem definidas por um conjunto de carências de equipamentos e de serviços coletivos; mas, no decorrer do tempo, a consolidação urbana se produz também nessas zonas que se transformam em novos subúrbios, sendo dotados, por setores específicos, dos equipamentos de base da vida coletiva.

Favela, espaço das classes perigosas ou do lupemproletariado: numerosos estudos mostram que, além dessas categorias impróprias, a favela abriga diferentes categorias de proletariado, ativo e inativo, e do subproletariado, assim como a pequena burguesia empobrecida, sendo que a importância relativa de cada uma dessas categorias evolui conforme a situação econômica geral. 
Favela, zona de desvio: ela pode, na realidade, exprimir a anomia; mas as populações das favelas criam uma importante rede de solidariedades primárias e de convivência.

Favela, interface entre o rural e o urbano: não pertenceriam elas mais, nem a um nem a outro mundo, como sustentam certos antropólogos? Ou então extrairiam elas seus recursos criativos dessa dupla origem, questionando a validade de uma visão rígida de separação entre o rural e o urbano, no contexto latino-americano?

Favela, fora do sistema político: numerosos trabalhos de ciência política mostraram que essas populações cooptam e são a presa de intensas correlações e negociações de forças políticas, das mais oligárquicas às mais radicais, tanto no autoritarismo quanto na democracia; outros acentuam com insistência seu caráter eleitoral errante.

Essas descrições empíricas foram objeto de importantes debates em torno do paradigma totalizante da marginalidade, segundo o qual o dualismo, o contraste, a segregação, a exclusão seriam o modo fundamental de funcionamento das sociedades urbanas latino-americanas. É possível, entretanto, detectar diferentes versões da marginalidade; as interpretações ecologistas que partem do quadro espacial para inferir conclusões em outros planos; as visões economicistas que, partindo do modo de inserção dos marginais no mercado de emprego, tiram conclusões relativas a seu modo e quadro de vida; e o politicismo, que condensa os dois níveis anteriores, numa interpretação em que predomina a vontade de fazer participar.

A qualidade da habitação funcionou como primeiro critério de recorte da realidade. Inspirada em trabalhos similares da Escola de Chicago sobre as cidades norteamericanas, uma corrente culturalista centrou primeiramente a reflexão no padrão de vida dos habitantes, que seriam sub-integrados e marginalizados no plano ecológico. Ao quadro espacial, acrescentavam-se a condição social dos habitantes, suas condutas e comportamentos sociais. Postulava-se a homogeneidade das realidades nesses planos diferentes e associavam-se empiricamente situações e comportamentos marginais em relação à habitação, aos salários, à educação, à saúde, ao emprego, à cultura e à política. A partir da teoria disponível na época, o culturalismo norte-americano, a categoria marginalidade foi redefinida, partindo não mais de características psico-sociológicas dos 
indivíduos e da constituição dos grupos sociais, mas das massas urbanas, em função dos traços dominantes da urbanização latino-americana.

Reconhecendo a especificidade de um processo de marginalização, que afetaria importantes contingentes de população, ampliou-se essa noção para mostrar a extensão dos fenômenos de desintegração social, de anomia e de individualismo. Os marginais não participariam senão passivamente, não interiorizariam senão debilmente as normas sociais e estariam separados das instituições urbanas. Essas conceituações eram coerentes com certas visões das sociedades latino-americanas, marcadas, então, pela contradição entre as tendências modernizantes e a desintegração social. Elas puderam também ser funcionais em relação a projetos políticos (sobretudo os da democracia cristã), baseados na intervenção dirigista do Estado para servir de paliativo às carências materiais e organizacionais (Vekemans, 1969). O imperativo da integração justificava políticas urbanas vindas de cima, e medidas visando tanto às necessidades imediatas, quanto à organização dos habitantes.

Vários trabalhos mostraram a ambivalência dessas políticas urbanas que, por um lado, desenvolviam importantes meios de modernização da cidade e, por outro, estabeleciam relações unívocas e verticais com as populações das favelas. Chegou-se até a reduzir a marginalidade a uma produção ideológica, emanando diretamente desse gênero de política. De acordo com uma ótica mais antropológica, inspirada pela análise da cultura da pobreza, a marginalidade foi considerada também como uma sub-cultura urbana, um modo de vida homogêneo, baseado em circuitos econômicos e sociais próprios, debilmente ligados à estrutura social global. Essa visão não postulava a passividade dos marginais: a pobreza induziria também condutas de solidariedade familiar, a permanência de valores folk e a criação de instituições informais, como as associações de migrantes ou a patronagem religiosa. Essas observações antropológicas não eram desprovidas de fundamento, mas a hipótese geral de uma cultura da pobreza (Lewis, 1961) foi amplamente questionada.

Essa marginalidade apareceu, então, como um mito, como uma construção pseudocientífica, desconhecendo o real, ignorando os fenômenos do poder. As análises ecológica e antropológica da marginalidade urbana foram abandonadas (e com elas todas as suas contribuições pontuais), porque fundiam artificialmente - atrás das fracas 
manifestações de acesso aos estatutos sócio-culturais - diversas dimensões de uma situação empírica. A marginalidade era concebida como um modo de vida particular, derivado do desenraizamento, das carências da estrutura urbana e da inserção precária no emprego. Era, pois, um tecido econômico, social e cultural, fracamente ligado ao pólo dominante da sociedade urbana. Visão falaciosa?

A teoria da dependência introduziu uma nova leitura da marginalidade, embora esta fosse defendida por várias correntes teóricas diferentes. Dependência e marginalidade são noções que funcionaram juntas durante o tempo todo em que se buscava um modo de desenvolvimento alternativo (independente e integrado). A análise econômica da marginalidade partiu de pré-noções relativas à fraqueza da inserção dos habitantes das favelas no mercado de emprego e pôde conduzir a um certo economicismo. A imagem de populações consideradas como totalmente instáveis, ligadas a atividades parasitárias e ao melhor do pequeno setor terciário urbano não produziu efeito. Numerosos estudos empíricos mostraram uma população muito mais heterogênea, compreendendo tanto mão-de-obra ativa estável, operários e assalariados, quanto artesãos e trabalhadores independentes.

Isso não impediu que o desenvolvimento da marginalidade orientasse a teoria para a compreensão dos principais mecanismos de constituição de um pólo marginal da economia, reagrupando os importantes contingentes de mão-de-obra, vítimas do desemprego e do sub-emprego. Esse argumento era baseado na defasagem entre uma dinâmica demográfica excedente (devida antes às migrações rurais que ao crescimento natural da população urbana) e a fraca capacidade de integração do aparelho de produção industrial. Os teóricos do dualismo econômico mostravam que o tipo de desenvolvimento dependente, com modernização parcial da produção, abria essa brecha no emprego. Alguns consideravam que essa última era apenas conjuntural e seria reabsorvida depois da transição; outros afirmavam seu caráter estrutural e crescente.

Essa interrogação deslocou-se, então, para a teoria marxista, que propunha uma categoria de análise ligada à leitura do desenvolvimento do capitalismo: a do exército industrial de reserva. Importantes debates ocorreram em torno da possibilidade de utilizar tal categoria no contexto particular da América Latina: segundo a teoria marxista, o exército industrial de reserva preenche a dupla função de contribuir para a depressão dos 
salários dos trabalhadores ativos e para fornecer uma reserva de mão-de-obra, que se incorporava nas fases de expansão do ciclo econômico. Essas duas ou uma dessas funções não pareciam estar preenchidas no âmbito do desenvolvimento do capitalismo dependente. Propuseram-se, pois, três linhas de interpretação opostas entre si:

- a de uma massa marginal que não seria expressão do exército industrial de reserva do capitalismo, mas da superpopulação relativa de um sistema, que combinava diferentes modos de produção e que produzia um elemento "disfuncional" (ou "afuncional") (Num, 1969);

- a de uma forma estagnada do exército de reserva que, dessa vez, no modo estrito de produção capitalista, permitiria efetivamente comprimir os salários dos trabalhadores, mas não seria nunca absorvida como mão-de-obra ativa (Singer, 1973);

. e uma análise mostrando que o desenvolvimento de uma base de emprego moderno na América Latina alimenta permanentemente o recurso e o desenvolvimento de estruturas produtivas complementares de pequena produção e de atividades terciárias, que se podem reagrupar sob o qualificativo de marginais.

Partindo de observações empíricas do urbano, a primeira interpretação remetia a considerações econômicas gerais, e levava logicamente aos modos de produção não capitalistas, localizados sobretudo nas zonas rurais. A segunda partia de uma interrogação mais centrada no perfil e na evolução da classe trabalhadora, e nas tensões políticas entre esta e os marginais. A terceira linha de interpretação talvez seja a mais urbana, já que vê, no desenvolvimento das grandes cidades latino-americanas, suportes materiais para uma acumulação do capital, não levando diretamente em conta importantes elementos da produção e da reprodução (daí, por exemplo, a combinação de atividades manufatureiras e industriais no processo de produção, ou os necessários complementos extra-salariais da reprodução da força de trabalho). Pôde-se criticar nessa discussão, e em geral nas polêmicas sobre o exército de reserva e a massa marginal, certo economicismo e um caráter estruturalista tomado ao marxismo althusseriano dominante. Viu-se aí também uma derivação teórica que não resultava em propostas analíticas concretas. De um modo geral, o debate sobre a marginalidade funcionou muitas vezes por 
anátemas, por esquecimentos, por reproduções e por exclusões, sob pretexto de orientações divergentes. Isso não impediu que a marginalidade tenha funcionado como mito fundador de uma pesquisa urbana especificamente latino-americana, permitindo ultrapassar o referente empírico da favela, e tirando das teorias dominantes categorias de análise específicas. Essa noção funcionou verdadeiramente como um paradigma, em torno do qual toda uma geração de pesquisadores tentou operar uma junção entre a apreensão das realidades e a elaboração conceitual. A margem aparece assim como um objeto transicional entre a teoria e a prática, do mesmo modo que ela faz o traço de união entre a cidade e o desenvolvimento. Com efeito, não se trataria de um paradigma dominante, quando se crê que um certo tipo de desenvolvimento, à la Ford, como se diria hoje, mesmo se periférico, é possível?

O consenso pôde desaparecer posteriormente, a tal ponto que, hoje, este paradigma é denunciado como ideológico, seja porque os debates teóricos não foram claramente definidos, seja por causa da evolução das realidades invocadas, que dificilmente se pode classificar como residuais: a margem está no coração do sistema, mais do que na sua periferia.

\section{3. Da marginalidade aos movimentos sociais}

Sigamos nossos quatro mosqueteiros, que vimos perambular na periferia da cidade, sem encontrar seu centro. Até aqui D'Artagnan conduzia o bando e conseguiu tirá-lo do pântano no qual todos teriam sido engolidos. O empirismo exagerado e o teoricismo obscuro, provenientes de uma mesma atitude para com a realidade, eram os principais perigos do caminho. Estamos agora às portas da cidade e esse segundo tomo tornar-se-á mais movimentado. É a vez de Aramis nos conduzir no campo do sócio-político. Na floresta da marginalidade, passou-se progressivamente da análise de situações à análise de condutas sociais para chegar aos processos. Certos autores, recusando o caráter estático das primeiras formulações, já haviam proposto falar mais de marginalização do que de marginalidade, centrando o debate mais nos processos históricos do que nas estruturas ou nas situações pontuais. Na fronteira, descobrem-se agora atores sociais. 
Desde o fim dos anos 60, a proliferação dos conflitos urbanos provocava uma reviravolta e polarizava a pesquisa urbana latino-americana em torno do que se convencionava, então, chamar movimentos sociais urbanos (Castells, 1970) ${ }^{20}$. Mais do que de anomia, falava-se de defesa comunitária (Vandershueren, 1970); mais do que de desorganização, de capacidade organizacional autônoma (CIDU, 1972); mais do que de carências, de reivindicações digiridas ao Estado (Bengoa, 1971); e mais do que de ambivalência, de consciência de classe (Duque et Pastrana, 1971 et 1972). Devido à conjuntura, essa mudança de ótica se produzia diferentemente e com importantes defasagens de um país para o outro: analisava-se ainda a marginalidade no Rio (Perlman, 1976), enquanto o conceito de movimentos urbanos irrompia em Santiago; e a literatura brasileira sobre os movimentos sociais é hoje abundante (Cardoso, R., 1983), enquanto tornou-se praticamente inexistente no Chile (Tironi, 1990). Além da mudança de ótica que a passagem dos processos aos atores implicava, mantinha-se uma certa continuidade entre essas duas categorias de análise, nem que fosse apenas numa referência empírica comum aos bairros populares, constituídos como quadro espacial essencial, senão exclusivo, de processos sociais e políticos de maior envergadura. Mas agora, as principais correntes culturalistas da marginalidade eram denegridas por terem inspirado governos conservadores para os quais os marginais representavam úteis reservas de classes de apoio e de legitimação, inclusive para manutenção de uma dominação oligárquica. A noção de ator estava ausente nessa interpretação. Assim, para os teóricos do populismo que postulavam, nas sociedades latino-americanas, ausência de uma clara hegemonia de classe, a pesquisa de alianças impunha às elites políticas o recurso à participação social para afrontar a dominação oligárquica (Rosembluth, 1963). O populismo podia desenvolver-se a partir de certa integração urbana, via moradia e serviços. Uma vez no poder, o populismo tornava-se uma prática de Estado, realizada de maneira vertical: utilizada assim, a noção de marginalidade era denunciada como uma muralha ilusória contra uma verdadeira mudança social. Sem serem definidas como um

\footnotetext{
${ }^{20}$ O conceito não deixa, naturalmente, de evocar o que Emilio Pradilla chama de marxismo urbano francês. Mas, na pesquisa das influências recíprocas, não é inútil lembrar que as primeiras análises das lutas urbanas voltam-se mais para o Chile do que para a Europa.
} 
ator autônomo, as camadas populares urbanas tornavam-se um elemento particular das relações entre Estado e sociedade, entre governantes e governados, entre classes dirigentes e camadas subalternas (Germani, 1971).

Para os politicólogos, preocupados com a estreiteza e a fragmentação da classe trabalhadora, a marginalidade era também um meio de reconsiderar as alianças de classe. Daí a importância dos debates sobre o caráter capitalista ou não, proletário ou não, da massa marginal. Alguns, apegados a concepções clássicas da direção de classe, viam, antes de tudo, os obstáculos colocados pelas práticas estatais a uma clara hegemonia dos trabalhadores sobre populações sem consciência de classe (Cardoso, F.H. e Faletto, 1969). Outros, mais influenciados pela redefinição das mudanças esperadas depois da revolução cubana, atribuíam uma maior importância à organização e à sublevação dos marginais, urbanos e rurais (Murmis, 1969). As massas urbanas, se eram suscetíveis de aderir a um projeto alternativo, ainda não eram, no entanto, um ator suscetível de definir um projeto próprio, mas tinham mais abertura que a classe trabalhadora, para quem quisesse fazer a "revolução na revolução".

Depois, o espaço de um populismo estatal urbano fechou-se, na maior parte dos países latino-americanos, como haviam feito as políticas trabalhistas e hegemônicas. Face ao Estado ou à classe trabalhadora, os diferentes segmentos das camadas populares urbanas pareciam constituir-se em protagonistas autônomos da ação coletiva. Foi, pois, a partir de propostas políticas consideradas como alternativas, que se postulou a emergência de um novo ator: os movimentos sociais tendiam a mostrar uma participação das camadas populares urbanas nos conflitos de classe e na dinâmica da mudança social. As mobilizações urbanas exprimiam os interesses dos pobladores, principalmente trabalhadores, mas compreendendo também elementos do semi-proletariado e da pequena burguesia. A base territorial desses movimentos fazia emergir ações protestativas e reivindicações pontuais (levando alguns a considerar que o movimento se esgota com a reivindicação), mas repetitivas (outros daí deduziam a longevidade desses movimentos). As organizações comunitárias de base, durante muito tempo cooptadas, apareciam agora como independentes e confrontadas com o Estado. Enfim, esses movimentos inscreviamse no quadro das contradições urbanas da urbanização capitalista, contradições 
classificadas como "secundárias", mas nem por isto totalmente desprovidas de conteúdo de classe.

Composição social, base territorial, reivindicações e contradições eram as palavras-chave para afirmar a pertinência de uma análise em termos de movimentos urbanos, novo ator da mudança, segundo a rigorosa hipótese dos movimentos sociais urbanos. Essa reconsideração estava ligada a uma vontade política e a estratégias, diferenciando os movimentos urbanos dos movimentos de trabalhadores ou de homens do campo. No plano da análise era preciso, no entanto, interrogar-se sobre a consistência, o potencial e a autonomia desses movimentos. Esses movimentos sociais eram lidos, primeiramente, segundo sua exterioridade, medindo-se os impactos que podiam produzir nas estruturas urbanas e nas correlações políticas. Uma outra releitura, inspirada na voga dos movimentos sociais, dizia respeito à base social que, segundo as normas ortodoxas da sociologia urbana marxista européia dominante, devia atravessar as classes sociais. No contexto latino-americano, esse policlassismo era restrito, uma vez que, salvo algumas lutas urbanas mobilizando a classe média, os movimentos sociais, partindo de uma territorialidade comum, mobilizavam mais as camadas populares.

A base social popular dos movimentos urbanos remetia, pois, de um lado, a uma homogeneidade social e a uma posição comum nas relações de classe, e, de outro, a uma diferenciação interna das camadas populares urbanas. A interpretação das lutas urbanas diferia segundo se acentuasse uma ou outra dessas características. Importantes debates opunham aqueles para quem o único referente de classe derivava das relações de produção, e os que viam no conflito urbano uma marca comum em relação ao consumo e à segregação urbana. Havia nessas querelas apreciações divergentes, tanto sobre a cidade quanto sobre a sociedade, e sobre as relações entre elas: o espacial reflexo do social, ou o social redefinido pelo espacial.

Quanto aos impactos, esperava-se desses movimentos sociais a constituição de um autor autônomo que deveria se articular com o sindicalismo operário ou remediar as suas deficiências principais. Certamente, várias experiências mostraram articulações pontuais entre lutas urbanas e lutas operárias, mas freqüentemente sem futuro. É nesse domínio que as discussões sobre os movimentos urbanos foram as mais importantes. As primeiras análises dos movimentos sociais invocavam uma explicação classista para sua 
emergência, a partir dos bloqueios dos canais tradicionais de expressão do proletariado: a autonomia desses movimentos é muito relativa. Posteriormente, observou-se que as mobilizações urbanas escapavam ao controle do movimento operário e de suas organizações sindicais e políticas. Os movimentos urbanos representariam, pois, uma modalidade específica de mobilização das camadas populares, num espaço próprio, e podendo levar a formas autônomas de consciência de classe. Ao invés de isolar-se na defesa contra a degradação das condições de vida, os movimentos urbanos surgiam como uma nova modalidade de expressão política.

Foi possível assim classificar vários tipos de movimentos urbanos, segundo essa grade de análise externa. No final dos anos 60, práticas urbanas adquiriam um novo estatuto, no Chile, depois no Peru, na Colômbia, na Venezuela e no México, sob a etiqueta de "movimentos de pobladores" (literalmente, movimentos dos habitantes dos bairros populares). Tratava-se de lutas urbanas que mobilizavam ora os sem-casa, ora habitantes de bairros já estabelecidos, nos conflituosos processos de invasão de terra, ou de resistência a operações de urbanismo, ou, enfim, de reivindicação material em torno das múltiplas carências de equipamentos coletivos. A organização popular e autônoma dessas lutas permitia opô-las aos modos clássicos de formação das favelas e de formulação de demandas, junto aos poderes públicos. De acordo com esses postulados, os movimentos de pobladores podiam se inscrever no horizonte teórico dos movimentos sociais urbanos, segundo os termos muito europeus da teoria disponível na época.

Alguns quiseram ver na categoria de pobladores a expressão de uma posição de classe, enquanto outros viam nela a referência territorial aos bairros populares. Em ambos os casos, postulava-se a emergência de um novo ator urbano, suscetível de intervir, enquanto tal, na cena política. Várias experiências levavam a depurar essas hipóteses. Objetava-se, por exemplo, que as lutas urbanas tinham um alcance apenas conjuntural e que sua visibilidade se apagava com a mudança de conjuntura e de estratégias políticas. Observava-se também que os movimentos territoriais, circunscritos ao local, chegavam raramente a se generalizar. Isso levava alguns a pensar que os movimentos de pobladores, instáveis e localizados, mostravam apenas uma débil capacidade de produzir alternativas sociais e políticas, para além dos objetivos materiais das reivindicações concretas. 
A noção de movimentos urbanos foi, posteriormente, estendida a ações reivindicativas, que ultrapassavam as bases de uma territorialidade circunscrita aos bairros populares. Eram, no Brasil, no Peru e na Colômbia, sobretudo, mobilizações em torno das carências dos serviços urbanos (transporte, água, eletricidade). Apresentandose sob um aspecto mais espontâneo e mais maciço, eles provocavam um animado debate sobre sua aparente espontaneidade. Movimentos de revolta contra os equipamentos e serviços urbanos, repetindo-se freqüentemente com um forte componente de violência, eles sugeriam a alguns a aparição episódica de um ator que, atuando mais com discrição do que com continuidade, não era menos presente na cidade. Para outros, tais ações revelavam-se mais defensivas que alternativas e sua incidência política não ultrapassaria o quadro da conjuntura.

Além das tradicionais reivindicações ligadas à terra e aos serviços de base, esses movimentos ocorriam também nas áreas da saúde, da educação, em torno das creches, das cantinas populares, dos centros de lazer, etc. Interrogava-se, então, a aparente autonomia desses movimentos e o papel real de seus leaders, na verdade articulados com as correntes progressistas da Igreja Católica e com partidos políticos. Não se tratava apenas do reforço de grupos políticos, mas de novas articulações entre os partidos e os movimentos sociais, quando igreja, partidos e organizações de bairros entravam em interrelação dinâmica.

O autoritarismo de Estado e a crise econômica iriam suscitar um terceiro tipo de movimento, de caráter mais protestatório: as revoltas, as greves cívicas, as jornadas de ação urbana, os protestos contra a carestia de vida ou em defesa dos direitos do homem. Quiseram ver aí uma expressão da revolta das classes subalternas contra o autoritarismo e, mais amplamente, uma polarização dos governos e das camadas populares. Espontâneas ou dirigidas, às vezes de grande violência, essas revoltas eram analisadas do ponto de vista de uma confrontação de caráter político, na qual o Estado parecia monolítico. Enfim, com o agravamento da crise, observavam-se tumultos generalizados, por ocasião de medidas impopulares, como o aumento do preço dos produtos de consumo corrente. As motivações de tais ações eram mais ligadas à sobrevivência, à profunda degradação dos níveis de vida, do que a objetivos propriamente urbanos. O fato de que elas tenham se realizado na cidade autoriza, no entanto, a falar de movimentos urbanos, 
sobretudo em situações nas quais é muito difícil separar a forma do conteúdo, ou o urbano do social. Essas manifestações de conflito urbano, classificadas na categoria cie movimentos sociais urbanos, percorriam a quase totalidade dos países latino-americanos, com especificidades de formas e de conteúdo, segundo a conjuntura na qual eles intervinham.

A sociografia dos movimentos urbanos, a partir de uma leitura externa de sua evolução e de seu impacto, não conseguiu chegar a uma definição consensual e durável. Alguns autores duvidam que esses movimentos tenham ultrapassado o contexto da conjuntura na qual eles se inscreviam e tenham desembocado no terreno do político de maneira autônoma. Alguns até mesmo vêem, na sua heteronomia e dependência de forças e direções políticas externas, uma reprodução das tradicionais relações de dependência, sob uma ideologia mais radical. Outros procedem a uma redefinição dos movimentos urbanos, afastando-se da concepção dominante da sociologia urbana marxista européia. Foi preciso levar em conta a trajetória multiforme e o horizonte histórico de movimentos que se tentou isolar demasiadamente em formulações mecânicas (estes pontos de vista diferenciados são substituídos em Slater, 1985, cf. capítulos de Evers, Henry, Kowarick e Laclau).

Mais recentemente, a nova realidade das mobilizações urbanas e da organização dos bairros populares exigiu uma releitura desses processos a partir de seu interior. As organizações comunitárias aparecem, então, como instâncias de expressão de identidade coletiva, de defesa contra a exclusão material e cultural e de expressão de estratégias coletivas de sobrevivência. Nessas análises, acentuam-se menos as relações entre o Estado e os habitantes do que os mecanismos internos de solidariedade. Anteriormente, análises similares de coesão interna das populações marginais não foram compreendidas devido a uma rejeição frontal de tudo o que emanava da teoria da marginalidade. Mas a solidariedade, canalizada pela organização, adquiriu uma nova importância, no momento de aconselhar os novos dirigentes que davam direito de cidadania às camadas populares. A coesão social, inverso da exclusão, só adquire realmente um sentido numa conjuntura de democratização quando ela pode desembocar no governo (Singer et Brant, 1980).

As formas de organização não estão mais, então, voltadas para a representação exterior, mas, sobretudo, para a coesão interna das comunidades. Os núcleos mais ativos

Rua, Campinas, 2:9-61, 1996 
não são formados pelos dirigentes tradicionais, mas por mulheres e jovens. Os objetivos da organização são menos orientados para as contradições secundárias do que para as formas de resistência familiar ou coletiva à crise. Tratar-se-ia, pois, da face autocentrada dos movimentos urbanos, que permite explicar sua profunda ambivalência entre a revolta contra a exclusão e a afirmação dos direitos sociais, entre a participação comunitária e a sublevação.

Essa ambivalência mostra a dificuldade de definir a capacidade da ação autônoma das camadas populares urbanas e a identidade de um ator do qual se pode acentuar tanto o potencial quanto as fraquezas, a capacidade de ação tanto quanto o recuo, a autonomia tanto quanto a dependência. Confronta-se assim com um problema típico da análise sociólogica na América Latina, onde os atores sociais parecem subordinados ao jogo político e onde o essencial da vida social repousa nas relações complexas entre atores que não parecem ter nem projeto próprio, nem capacidade autônoma de direção (SUR, 1989).

A problemática dos movimentos sociais, confrontada às dificuldades teóricas, tornou-se menos evidente na pesquisa urbana latino-americana com o agravamento da crise econômica, que induziu a um certo refluxo da ação coletiva organizada e está mais propícia a revoltas urbanas de caráter espontâneo. Oscila-se, pois, entre a negação de uma categoria unificadora (ou enganosa) e a afirmação do caráter específico dos movimentos sociais na América Latina. Interroga-se, igualmente, o conteúdo cultural desses movimentos, as características de seus leadership (participação majoritária das mulheres), a emegência de novas solidariedades, e, sobretudo, o alcance político da confrontação com o Estado. Abandona-se, pois, a análise clássica das contradições urbanas nos meios de consumo coletivo, para analisar a relação dos movimentos sociais com os diferentes escalões do poder.

A passagem da marginalidade aos movimentos urbanos revela-se, pois, mais como deslocamento do que como ruptura. Na verdade, os passantes deram as costas a seus predecessores. Mas, muito mais que o mimetismo em relação a uma categoria que fracassou na Europa, a criatividade desse tema é notória na sociologia urbana latinoamericana, mesmo que seu balanço teórico ainda não tenha sido feito. Simples invocação, retórica desgastada? Não se pode, entretanto, pensar a alteridade dos 
habitantes, que se tornam-se cidadãos pela prática social, como menos ainda se pode governar a cidade sem ação coletiva. Aramis aí está para nos lembrar isso, no final de um episódio que vê, finalmente, a marginalidade e os movimentos urbanos como as duas faces de uma mesma moeda de ouro ${ }^{*}$. E essa é a decifração do enigma desse segundo tomo do romance da nossa juventude.

\section{3. $O$ Visconde de Bragelonne, ou o objeto redescoberto}

O último tomo da trilogia de Dumas põe em cena os mesmos protagonistas, numa ação menos épica, cujo fio condutor é menos evidente. Não é fácil encontrar as jóias da rainha, muito menos as chaves da cidade: e ainda é preciso saber claramente qual é o objeto procurado. Assim também, uma distância marca a passagem dos dois movimentos de pensamento anteriores da pesquisa urbana latino-americana, inscritos numa certa continuidade de contexto e de elaboração que têm como testemunho a polarização dos debates, e os que seguirão, onde o consenso na unidade do campo e da reflexão é menos patente.

\subsection{Dos movimentos sociais ao poder local}

A multiplicação dos conflitos urbanos orientou a reflexão para a necessidade de entender melhor os movimentos sociais, tanto em relação ao resultado das reivindicações concretas quanto em relação à representação política. Chega-se aos problemas do poder local. Como pano de fundo dessa reflexão, coloca-se um verdadeiro problema; o do governo urbano. Falou-se tanto, anteriormente, do poder local, que se deveria estar em condições de vê-lo prolongar-se em diferentes escalas (aglomerações, municipalidades ou bairros), em diversas áreas (política, econômica ou técnica) e segundo diversos ângulos de abordagem (globalizantes ou setoriais). As condições da democratização e,

\footnotetext{
" (N. do T. "Louis d'or", no original)
}

Rua, Campinas, 2:9-61, 1996 
paradoxalmente, da crise favoreceram essa mudaça temática, que não está ainda consolidada em todos os países (Borja, 1989).

Esse tema é, primeiro, conduzido, no plano institucional, pelos movimentos sociais. A redundância dos conflitos e a repetição de experiências reivindicativas, ou de solução coletiva dos problemas comunitários, consolidaram progressivamente a organização dos bairros populares. Esses conseguiram, de maneira desigual, dotar-se de níveis superiores de representação. Atenuaram-se as fronteiras entre a cidade legal e a cidade ilegal, entre o centro e a peiiferia, entre o integrado e o segregado, pelo menos no plano espacial. Em outras palavras, a exclusão econômico-social tende a invadir o centro da cidade. Tem-se, pois, um jogo complicado de conquista/recusa da cidade, por tudo aquilo que as camadas populares carregam consigo historicamente e existencialmente. Não é mais o cara a cara, mas a luta de poder entre duas (ou várias) maneiras de viver na cidade. As organizações de bairros, agrupando-se em zonas, em circunscrições administrativas, em municipalidades ou aglomerações, chegaram, por vezes, a atingir níveis regionais e nacionais de federação. Processos similares se produziram em torno dos equipamentos e serviços coletivos, a partir dos comitês de usuários ou de populações afetadas por fenômenos tais como inundações e terremotos. Enfim, organizações menos formais, mas talvez mais representativas de sua base social, partindo dos clubes de mães, dos grupos culturais ou das comunidades eclesiásticas, adquiriram também uma representatividade real.

Observa-se assim uma grande densidade e uma forte diversidade de organizações populares afirmando-se, a títulos diversos, como instâncias de expressão das camadas populares urbanas. Elas se definem, muitas vezes, como organizações populares, o que vem a situá-las mais em relação ao Estado do que às classes. Sua representatividade é inversamente correlativa ao poder das organizações tradicionais da sociedade civil: sindicatos, empresas, igrejas. Elas são também consideradas enfaticamente pelos partidários da democratização das sociedades latino-americanas, que procuram, na persistência da ação coletiva, eixos de orientação para uma renovação do político.

A visão dicotômica, movimento orgânico contra o Estado monolítico, é progressivamente contestada e preconiza-se uma articulação entre as práticas populares e as intervenções públicas na questão da moradia (Sachs C., 1990). Parece não haver 
solução que não passe por uma mobilização das energias e dos recursos de base, com o apoio dos aparelhos estatais. A auto-construção assistida torna-se um paliativo irremediável e tem sua revalorização nas pesquisas que priorizam, de um lado, a insolvência das populações carentes e, de outro, os limites da intervenção dos poderes centrais. Assim, o ayllu, a mita, o mutirão não têm sentido, nas cidades de hoje, se não envolverem uma mobilização dos recursos públicos (Maricato, 1979). Essa revalorização é apoiada pela intervenção de organismos internacionais tais como o Banco Mundial, que mantêm programas de loteamento estatal e de construção popular - Sites and Services (Cohen, 1991). Experiências mostram, então, a potencialidade da mão-de-obra popular na produção do espaço habitado, cuja iniciativa compete às organizações de base, mas se beneficiam de ajudas públicas. O desenvolvimento das organizações de base leva a revalorizar essas práticas de auto-construção assistida e a considerar formas de gestão baseadas na participação social. Da produção de habitações e equipamentos, passa-se a uma gestão autônoma do controle e do financiamento desses programas ditos participativos (Durand-Lasserv, 1986).

Além da habitação, as organizações urbanas reivindicam, hoje, o acesso aos equipamentos e aos serviços coletivos (Dupuy, 1987): primeiro o transporte, na medida em que representa um elemento indispensável de conexão entre o centro e a periferia, em aglomerações ainda muito dependentes dos transportes coletivos (Henry e Figueroa, Cuidad/Inrets, 1986 e 1987). A construção ou organização da rede viária podem ser o objeto de uma participação comunitária em programas públicos. Mas, o mais das vezes, as intervenções públicas ocorrem a partir da pressão dos moradores.

O serviço de transporte coletivo é, na maioria dos casos, produzido pela iniciativa privada, que presume-se ser controlada em nível federal ou, em seu último escalão, em nível municipal. A tutela do poder público nesse serviço concedido é, na maioria das vezes, discreta demais, resumindo-se ao reconhecimento dos prestadores de serviço e à determinação dos parâmetros de base, tais como a aquisição dos veículos ou à fixação de tarifas. A intervenção das organizações populares nessa área reveste-se de diversas modalidades, além das revoltas regulares contra os preços ou contra as condições de transporte. Conhecem-se algumas tentativas de auto-produção dos serviços de transporte nos bairros populares. Assiste-se também à criação de órgãos de gestão, baseados na 
participação social, notadamente para a fixação das tarifas, em que as organizações de bairro exercem um direito de controle sobre as empresas prestadoras de serviços, em associação ou em substituição às autoridades governamentais. Enfim, as organizações populares reivindicam constantemente que o Estado se encarregue do serviço público, em nível local. As empresas públicas de transporte, amplamente minoritárias e essencialmente apoiadas pelas empresas privadas, são, no entanto, pouco favoráveis à participação popular...

Sempre visando à melhor compreensão dos movimentos sociais, as pesquisas sobre os serviços urbanos (Coing e Montaño, 1986 e 1989) analisam também, em menor escala, a água (mais que o saneamento), a eletricidade ou a coleta de lixo. Interessam-se mais pela instalação desses serviços, sob pressão popular, e pela fixação de tarifas, do que pela produção dos mesmos. Estudam as mobilizações em torno desses serviços de base e mostram o caráter aglutinador dessas reivindicações (Jacobi, 1982). Mostram igualmente a extrema dificuldade de conciliar reivindicação e participação, numa lógica em que os serviços urbanos se distribuem segundo os princípios da segregação. Assim, tais serviços mobilizam menos na medida em que tratam de questões mais localizadas do que as questões dos transportes.

Esses serviços podem ser algumas vezes auto-produzidos, pelo menos parcialmente, mas implicam, na maioria das vezes, relações entre usuário(s), empresa(s) prestadora(s) de serviço e organização de base. São relações conflituosas, tanto mais porque os serviços públicos apresentam diversas manifestações de crise: crise de financiamento, de investimento, das políticas e programas públicos, de formas organizacionais da oferta, etc. Aliás, crise estrutural, duas vezes maior na atual conjuntura de desengajamento dos governos centrais. Em contraposição, pois, as organizações locais constituem órgãos de pressão popular, onde se consideram as reivindicações e se articulam as problemáticas setoriais - relações entre os problemas de transporte, de água, de saneamento, etc. - (Coing et Henry, 1989).

Na última década, essa nova forma de abordar os serviços urbanos, partindo dos movimentos sociais, marca fortemente a produção intelectual sobre o assunto. Chega-se a uma reinterpretação da noção de meios de consumo coletivo, no quadro do capitalismo periférico, com a constatação das carências das intervenções estatais, em matéria de 
reprodução da força de trabalho, que não estão ao encargo do capital. Fala-se, por exemplo, da "espoliação urbana" para designar as distorções feitas na reprodução da força de trabalho, encontradas nas condições de vida urbana e, notadamente, no acesso aos equipamentos e serviços coletivos. E, finalmente, interroga-se sobre a validade dessa noção no contexto da crise capitalista (Jaramillo, 1985).

As organizações de bairros puderam ser consideradas como alternativas às formas tradicionais de representação urbana (contra-poder, utopias radicais), mas elas tiveram como consequiência, sobretudo, o problema da participação cívica e, além da confrontação, o problema de seu reconhecimento pelos aparelhos estatais, nos diferentes escalões. Foi em nivel municipal que essas organizações puderam provocar o maior número de modificações e obter certo direito de cidadania, sob diferentes formas, no Peru, no Brasil, na Colômbia, no Equador, na Venezuela e no México. Pesquisas realizadas nessa área mostram que as organizações de bairro guardam um caráter mais reivindicativo do que administrativo. Elas demonstram, porém. uma ascensão quanto ao poder das organizações populares que, originando-se nos bairros e se elevando a níveis superiores de representação social, conduzem ao problema da representação cívica. A pesquisa urbana latino-americana hesita em seguir os passos daqueles que vêem, nessas redes e trajetórias, novas formas democráticas, transcendendo as formas tradicionais de representação política.

Esse renascimento do interesse pelos serviços urbanos procede também de um outro movimento, o da descentralização da gestão urbana. Os numerosos estudos sobre as políticas de habitação na América Latina e sobre as políticas de integração social, assim como sobre aquelas mais raras, as políticas urbano-regionais, os investimentos e as políticas de infra-estrutura e de equipamentos sociais, norteiam uma nítida retirada da intervenção do Estado, na última década. As ambiciosas políticas urbanas dos anos 60 muitas vezes deram lugar a medidas mais centradas na gestão daquilo que já existe. Nesse contexto, a instância municipal procurava encarregar-se das competências de regulações dos conflitos que escapavam à capacidade dos aparelhos centrais. A crise econômica reforçou essa tendência ao deslocamento das competências do poder central para os poderes locais: racionalização orçamentária, limitações das despesas não diretamente produtivas, redirecionamento dos investimentos para as necessidades 
ao acúmulo de capital. Aparecem, então, fórmulas tais como a desconcentração, a descentralização e a privatização, que destinam efetivamente um papel novo aos órgãos inferiores das estruturas estatais (De Mattos, 1987). Os meios financeiros e materiais das coletividades locais nem por isso são reforçados, mesmo quando estas são democratizadas e aumentam suas áreas de competência.

Anteriormente, a extrema politização dos problemas urbanos havia levado a um antagonismo entre políticas concebidas e aplicadas pelo poder central e as organizações populares (Nunes, 1986). Por outro lado, as instâncias intermediárias de poder haviam, progressivamente, perdido sua legitimidade, sua representatividade e sua capacidade funcional para gerir os problemas das cidades. As municipalidades latino-americanas pareciam apêndices terminais dos aparelhos do Estado, mais do que coletividades locais autônomas. Variando de um país para outro, a organização municipal correspondia, na maioria das vezes, a um modelo arcaico e vertical fortemente dependente do Estado central. A autonomia do princípio do poder municipal, assim como seu leque de competências eram desrespeitadas por práticas autoritárias de invasão do campo municipal pelas autoridades centrais. A dependência das coletividades locais era, ao mesmo tempo, financeira e política: ausência de recursos estáveis e ausência de democracia na designação dos edis. A precariedade financeira das municipalidades tornava-se preocupante, num momento em que os governos centrais tentavam desfazer-se dos problemas dos serviços. Era preciso, pois, adotar medidas que permitissem seja aumentar a transferência de fundos para as municipalidades, seja reduzir os custos de investimento ou de exploração dos serviços, devido a um desengajamento dos poderes públicos. O que está em germe é um conflito político entre poder local e poder central. A municipalidade não poderia mais ser um simples apêndice deste último, e tornou-se necessário abri-lo a um jogo político mais democrático.

Assistiu-se, na última década, a reformas das municipalidades de vários países latino-americanos, através de um reforço de sua autonomia econômica, administrativa e/ou política. Muitas vezes elas recuperaram competências em matéria de prestação de serviços à população, sem por isso dispor dos meios necessários. A concessão desses serviços a sociedades privadas tornou-se, pois, às vezes, uma obrigação para municipalidades que se viam na incapacidade de assumir suas responsabilidades. 
A mudança de status e/ou de funções interveio, em graus diversos, paralelamente à transferência das competências do poder central para o poder local. Por um lado, democratização, em virtude da mudança do modo de designação das autoridades, situação em que a eleição direta tende a generalizar-se; por outro lado, democratização, em razão da instauração de mecanismos de participação da população na gestão local. Novos canais de participação popular foram abertos em diversos países, sem que se possa dizer que essas reformas tenham tido sistematicamente um caráter progressista. Foi possível, algumas vezes, estabelecer o renascimento de um clientelismo local e, em outros casos, mostrar a institucionalização dos órgãos populares de representação dos habitantes. A participação social adquire, assim, conotações variáveis, segundo os países e as conjunturas políticas globais, bem como segundo os setores aos quais ela se aplica. Alguns estudos recentes tentam elucidar a relação que se estabelece entre a descentralização político-administrativa, a autonomia municipal e a democratizaçãoparticipação popular.

$\mathrm{Na}$ atual conjuntura de crise que marca, em graus diversos, todas as economias latino-americanas, a capacidade do Estado de executar políticas de redistribuição, através dos programas sociais, diminuiu sensivelmente. Opta-se mais pela privatização e pelo mercantilismo desses serviços, por sua gestão municipal ou pela auto-produção. Observase aí um novo ponto de encontro, e de conflito, naturalmente, entre as formas estatais e as formas populares de poder.

Há estudos, por exemplo, que tratam dos programas de emprego mínimo ou de assistência alimentar, implicando a participação direta ou organizada da população. Sua significação real depende do conteúdo da relação entre os governos nacionais ou locais e as populações. Outros estudos postulam práticas de autogestão, remontando à sociedade civil, a partir de atividades empreendidas pelas comunidades de base, em substituição aos poderes públicos. Assiste-se, assim, a um novo desafio da gestão urbana, dividida entre a afirmação de um poder local e o desejo de responder às necessidades alardeadas pelas organizações representativas dos habitantes. Esse desafio é redobrado com o crescimento dos bairros periféricos, o acúmulo das carências de equipamentos e a intensificação dos mecanismos de segregação espacial. Desafio lançado também à pesquisa urbana, para 
que ela avance na análise do poder local, largamente tributária do estudo dos movimentos sociais.

\section{2. Retorno do informal}

Um estranho personagem assombra os corredores da pesquisa urbana. Um personagem cuja dimensão cresce cada dia e que, por sua vez, parece invadir a cidade. Um personagem que, para sobreviver, parece menosprezar toda urbanidade. Estamos no auge da crise, mas Porthos pensa ter reconhecido, através dos traços do informal, uma velha amizade de nossos companheiros de aventuras (Santos, 1978, 1979).

Realmente, uma parte importante da economia urbana, deslocando-se para a pequena produção comercial de bens e serviços, pode mais ser qualificada de setor de refúgio, na medida em que se tornou altamente competitiva em relação a formas de produção privadas ou estatais. Seria efeito da urbanização ou da crise? Não se ousa mais invocar o modo de desenvolvimento, uma vez que os debates sobre a marginalidade são recentes. É bastante paradoxal constatar-se que, justamente quando recuou no plano da teoria, a marginalidade parece voltar com toda a força na realidade. Esse retorno a preocupações de outrora mostra quanto a pesquisa deve constantemente percorrer um campo polifacetado e não pode, afirmando-se em certas disciplinas, afugentar as outras. O retorno do informal traz de volta o econômico, na linha de frente (PREALC, 1981).

Mas a teoria da informalidade (Tockman, 1979) é inovadora em relação à sua ancestral, a da marginalidade: esse setor não é mais considerado como o reverso, mas como o verso da medalha do desenvolvimento em si. Longe da euforia da industrialização, somos obrigados a lançar um olhar mais positivo sobre as coisas. Alguns chegam até a postular uma reviravolta estrutural e a dominação progressiva de uma economia alternativa. Ao contrário da marginalidade, a informalidade é considerada como um fenômeno essencialmente urbano. Mas não se pensa em agir nos comandos da cidade para contê-lo. De maneira bem empírica, trata-se, sobretudo, de revalorizar a economia urbana de base popular, economia que se havia qualificado anteriormente de 
marginal e que seria hoje a única esperança de desenvolvimento, pelo menos para os adeptos do neoliberalismo econômico (De Soto,1989).

Evidentemente, o setor qualificado de informal é uma importante fonte de renda e de emprego para as categorias da população que constituem a base do poder local. Essas razões econômicas e políticas levam a um certo reconhecimento e a uma formalização do informal. O poder, municipal ou outro qualquer, é dessa forma chamado a legitimar e a defender micro-experiências produtivas, a tomar medidas de reconhecimento das atividades urbanas, anteriormente consideradas como clandestinas, enfim, a executar programas de emprego mínimo. Abre-se, então, todo um espaço de negociação entre as formas clássicas de legislação e de regulação municipal e os responsáveis pela economia informal. É daí que se origina uma nova reflexão sobre a pesquisa urbana latinoamericana (Urriola, 1988).

Do mesmo modo que, em períodos anteriores, canalizou-se a atenção para os meios de consumo coletivo, hoje são as estratégias de sobrevivência e as dimensões individuais e familiais da reprodução social (Friedman e Salguero, 1987) que merecem a atenção dos estudiosos. A forma dos conflitos urbanos incita a isso, já que predominam sobretudo ações de massa, tais como tumultos, saques e explosões de violência. É ainda, porém, porque se assiste a um crescimento das organizações ditas funcionais nos bairros populares, em oposição às que têm uma conotação mais política. Enfïm, num período de restauração democrática, o comportamento eleitoral das camadas populares traz surpresas e nos convida a nos debruçar sobre problemas anteriormente considerados como estranhos à pesquisa.

Descobre-se, assim, a importância das mulheres na vida do bairro e seu papel preponderante na organização coletiva da sobrevivência (Feijóo e Herzer, 1991). Durante muito tempo reduzidas, inclusive pela análise, a um papel de simples suporte do acúmulo e da reprodução de uma força de trabalho essencialmente masculina, as mulheres do setor informal aparecem hoje como um elemento vital da economia do bairro e da família. Começa-se, pois, a interessar-se por suas atividades, tanto produtivas quanto ligadas a uma função de socialização. A infância e a educação constituem igualmente objeto de novos trabalhos de pesquisa (Carrión, D. e Vaistoc, 1987). Alguns pensam residir aí uma volta importante das teses culturalistas, ao passo que outros falam da emergência de 
novos protagonistas e de novas áreas de ação coletiva, a serem, pois, conceituados numa teoria da mudança.

Se a solidariedade, a criatividade e a cultura populares são, então, revalorizadas, elas o são, na verdade, sob o duplo efeito de uma atenção dada pelos pesquisadores aos problemas imediatos da consciência e da vida cotidiana, e de um convite formulado explicitamente pelas instituições estrangeiras de ajuda ao desenvolvimento e de luta contra a pobreza. Porém, estas não parecem mais ser portadoras de um projeto mistificador de assistência, dirigida politicamente, como foi o caso nos períodos de expansão do populismo latino-americano. Fica, pois, como um verdadeiro desafio lançado à pesquisa, a tarefa de descobrir os caminhos para os quais conduzem essas formas de sociabilidade urbana (Gilbert, 1982).

O desenvolvimento daquilo que tende a tornar-se o paradigma da informalidade se produz em condições opostas às que ocorreram com a marginalidade. Do mesmo modo que esta era considerada como um avatar da modernização e de seus corolários - a industrialização e a urbanização - ocorrem hoje fenômenos duráveis de crise, de estagnação, até mesmo de recessão econômica, em sociedades em que a urbanização é um fato adquirido. A informalidade adquire, assim, um novo sentido, o da resistência dinâmica às evoluções de cidades em crise.

Outra especificidade da informalidade: sua projeção política. Por mais de uma razão, as realidades contidas nesse epíteto parecem ser as mesmas dos anos 60, mesmo tendo mudado profundamente o contexto enconômico e urbano. Mas, naquela época, elas vinham cobertas por um manto progressista, pelo menos em aparência. Sua nova denominação não hesita em revestir-se de uma visão anti-estatal virulenta (INLIDE, 1987). Pode-se até dizer que, para alguns - que estão longe de ter descoberto uma realidade nova - a novidade de sua produção repousa nessa diatribe contra a ingerência de um Estado hipertrofiado, incompetente e hiper-regulamentador. A solução consiste, pois, em desregulamentar, o que não deixa de estar de acordo com as injunções dos organismos internacionais que preconizam o reajuste estrutural nem com certas teorias novas que pontificam no exterior. Vários autores, baseando-se em numerosos trabalhos de pesquisa, denunciam o ingrediente ideológico do liberalismo que acompanha muitas vezes esse novo discurso dominante. Porque a maioria das atividades informais não se 
desenvolve em função das exigências de burocracias pletóricas, mas, muitas vezes, no seu planejamento, ou pelo menos, com sua cumplicidade. Que seria o transporte informal sem o apoio indireto, ou até direto, dos poderes privados? Como operaria o comércio ambulante, sem todo o sistema de organização do mercado de atacado e varejo, codificado e segmentado pelas autoridades tutelares? E como funcionaria a indústria da construção, sem esse formidável componente de sub-empreitada e de mão-de-obra, formada no próprio local, na favela?

Um exemplo que pode parecer anedótico, mas não deixa de ser significativo, é o caso do narcotráfico, hoje pólo dominante das economias colombiana, peruana, boliviana ou panamenha. Desde que se possa falar de um setor totalmente informal - que se origina tanto nas zonas de produção de coca quanto nos laboratórios de destilação dos bairros populares - este irriga toda a economia urbana pelas atividades paralelas de comercialização e de financiamento. Foi possível mostrar que mais de um projeto de desenvolvimento urbano estava ligado aos imperativos de lavagem dos narcodólares, e que o desenvolvimento inteiro de uma região, outrora tão industrializada quanto a Antioquia, hoje depende dela profundamente. Mesmo a fortaleza cubana paga um alto tributo a essa excrescência do capitalismo especulativo.

A informalidade é agora também descodificada como princípio portador de uma ordem alternativa, substituindo o princípio que presidia, pelo menos nas aparências, a vida urbana. Para alguns, trata-se de um transbordamento popular e, para outros, o caminho alternativo, aquele que corresponde aos iluminados que pretendem ainda continuar a guerra social, desde a libertação dos campos até o cerco e a submissão das cidades (e que têm nos fatos o fator principal de expulsão do homem do campo para as favelas: os migrantes de guerra). Na sua primeira manifestação, essa ordem é feita de espontaneidade, mas também de violência, à imagem daquela que é induzida pelo narcotráfico. A violência urbana tornou-se, assim, um tema de pesquisas, em suas manifestações mais casuais como mais coerentes, num contexto de crise e de dissolução da normatividade formal. Não se está longe da anomia (e de se encontrar uma velha tese dos marginalistas), na medida em que essa violência seria capaz de destruir os próprios princípios da organização (Hardoy e Moreno, 1974). 
A informalidade leva também a se refletir sobre as bases do direito, sobre sua aplicação ao contexto das realidades urbanas, sobre as fontes de produção de normas alternativas, sobre as potencialidades e limites do exercício de uma autoridade consentida e conforme às necessidades das populações. As disciplinas jurídicas, até aqui amplamente ausentes da pesquisa urbana, emergem hoje na convergência da democratização da vida local e do reconhecimento e sistematização das práticas de base. Encontram-se certos elementos da reforma urbana, mas esta é colocada em termos diferentes daqueles dos anos 60.

\section{3. Da trajetória às perspectivas}

Por trás desse retorno ao informal, vê-se, pois, um estilhaçamento da pesquisa urbana latino-americana, que alguns assimilam a uma dispersão, e outros a uma diversificação em direção ao econômico, ao cultural ou ao jurídico. O retorno do informal seria uma vingança da realidade sobre o discurso? Paradoxalmente, o momento atual é também marcado por duas tendências: a abertura das problemáticas e a consolidação dos meios de pesquisa.

Além das pesquisas provocadas pelo retorno do informal, vêem-se, hoje, pesquisadores se apaixonarem pela história das cidades ou dos bairros: observa-se uma antropologia, durante muito tempo confinada nos campos; sente-se uma nova preocupação pelos fenômenos ligados à degradação do meio ambiente urbano; notam-se as dimensões das catástrofes naturais tais como os terremotos ou as inundações, e reconhece-se uma tecnicidade apurada na análise dos problemas urbanos. Com efeito, essas evoluções podem ser criticadas como modos ou temas impostos; no entanto, elas têm uma relação evidente com as realidades, e são sempre analisadas num ângulo social. Por exemplo, um tema tão afastado do social quanto as catástrofes naturais desemboca numa análise fina e pragmática da importante organização dos sem-teto depois dos terremotos do México. Resta determinar como essas pesquisas contribuem para melhor definir o objeto de pesquisa, a saber, a cidade latino-americana. E, mais adiante, resta estabelecer em que esse objeto é ainda pertinente. É talvez no momento em que se 
chegou ao centro, quando se tem nas mãos as rédeas do poder, conquistado a duras penas, que se tem maior dificuldade em se distinguir uma perspectiva. E é como se a crise tivesse reduzido a cidade latino-americana à imagem do centro do México ou de Manágua, depois de seus respectivos terremotos... Paralelamente, assiste-se também a uma institucionalização da comunidade científica latino-americana interessada pelos problemas urbanos. Uns trezentos pesquisadores, umas cinqüenta equipes, departamentos de urbanismo das principais universidades, uma dezena de centros especializados na promoção e análise dos problemas urbanos confirmam nosso diagnóstico da perenidade extraodinária desse campo de pesquisa.

Rio acima, é preciso agora retomar Os três mosqueteiros para encontrar os traços de personagens e de mensagens que parecem hoje esquecidos, enquanto suas vozes se ouvem em surdina. E rio abaixo, conviria tentar adivinhar para onde se dirigem os cavalos de nossos heróis, para melhor apreciar sua contribuição para o desbravamento do caminho que leva à cidade. Na espera, suspendamos nossa leitura, antes de descobrir seu enigma romanesco. Chegaremos, como propõem alguns, a um paradigma unificador? Ou, em outros termos, a uma utopia realista de cidade para todos, democrática ou repensada?

Seria necessário, para elucidar o mistério da seqüência invadir, aconselhar, governar, reconstituir um histórico dos enunciados que formam o discurso sobre a cidade latino-americana, inspirando-se nas recomendações de Michel Foucault, na sua arqueologia do saber $^{21}$. Observa-se, na verdade, com que obstinação o pensamento latino-americano sobre a cidade volta constantemente atrás, para reler noções que havia

\footnotetext{
21 "A história das idéias é, pois, a disciplina dos começos e dos fins, a descrição das continuidades obcuras e dos retornos, a reconstituição dos desenvolvimentos na forma linear da história. Mas ela pode, também, e por isso mesmo, descrever, de um domínio a outro, todo jogo das trocas e dos intermediários: mostra como o saber científico se difunde, dá lugar a conceitos filosóficos, e, eventualmente, toma forma nas obras literárias; mostra como problemas, noções e temas podem emigrar, do campo fillosófico em que foram formulados, para discursos científicos ou políticos; estabelece relação entre obras e instituições, hábitos ou comportamentos sociais, técnicas, necessidades e práticas mudas; tenta fazer reviver as formas mais elaboradas de discurso na paisagem concreta, no meio de crescimento e desenvolvilmento que as viu nascer. Torna-se então a disciplina das interferências, a descrição dos círculos concêntricos que cercam as obras, que as valorizam, as ligam entre si e as inserem em tudo o que não são elas." (Cf. Foucault, 1969: 180).
} 
abandonado, apesar das mudanças de gerações de pesquisadores, e, sobretudo, das evoluções radicais das realidades. Parece, então, secundário escalonar o tempo dessa pesquisa, segundo as conjunturas atravessadas pelo continente, pois, no fundo, essa volta constante das noções, mesmo quando estas partiram das pré-noções da linguagem popular ou mediática, pode tanto marcar o não acabamento de uma elaboração problemática, quanto a descoberta de um real atingindo a essência da cidade.

Seria então uma ambição à altura das realidades abordadas, e não se pode, além disso, esquecer que estamos na cidade, no coração de uma reflexão sobre o social, como observavam os precursores da pesquisa latino-americana.

\section{Epílogo: a cidadania, chave da cidade?}

D'Artagnan e seus companheiros poderiam ainda por muito tempo procurar as jóias da rainha, se, relendo suas aventuras passadas, não tivessem descoberto um índice casualmente escondido na dificuldade de se traduzir, tanto em espanhol, quanto em português, a palavra "citadin". E, no entanto, as cidades latino-americanas são densamente povoadas, e seus habitantes aqui às vezes qualificados de "cidadãos", com uma pitada de desconsideração transparecendo na boca de quem quer assim reduzir um sujeito ao único fato de pertencer a uma identidade fictícia, ou a um Estado sem grande noção de nação...

Por trás dessa dificuldade de vocabulário, nossos aventureiros encontraram um butim tão conseqüente quanto o que trouxe de volta Aureliano Buendía, e não menos imaginário que a Macondo para onde volta sem cessar este coronel, caminhando a passos largos pela América Latina, como grande fundador de realidades tão originais quanto transcendentais. Aos olhos do colono, esse butim pode assemelhar-se às quinquilharias falsas com as quais os conquistadores maravilhavam tanto os bons selvagens; mas, o vice-rei aí encontrava seu peso em ouro ${ }^{22}$, que o cabildo hispânico soube bem drenar, sob o disfarce de democracia local, assim como os portugueses e outros conquistadores

\footnotetext{
22 "Louis d'or", no original (N. do T.).
} 
europeus souberam transformar o pau-brasil num país de exportação de uma única essência, com a ajuda dos corpos de ébano... Cinco séculos depois, o ouro e as madeiras preciosas tornaram-se raridades, mas sua exploração deixou vilarejos e fronteiras que, de uma revolução a outra, tornaram-se cidades e países, metrópoles e Estados; e seus habitantes, cidadãos, segundo a dupla acepção ibérica do termo.

Será mesmo assim? Essa é uma questão que preocupa hoje a comunidade dos pesquisadores latino-americanos que se interessam de perto pelos problemas urbanos, e cuja identidade profissional está sendo agora um tanto questionada. Tantas caminhadas e cavalgadas nas ruelas dos cortiços, através das ruas dos bairros em formação, pelas praças de cidades em construção ou acima das megalópoles em desenvolvimento, permitiram-lhes acumular mais imagens fragmentárias do espaço ou dos habitantes (Santos, 1990) do que um alforje poderia conter, mesmo o de um arquiteto ou de um engenheiro, de um historiador ou de um geógrafo, de um sociólogo ou de um antropólogo, nem mesmo o de um urbanista ou de um teólogo. O sentido da cidade, entretanto, não se impôs ao olhar deles.

As caixas de ferramentas desses profissionais do campo urbano não continham o instrumento indispensável que permite ao botânico fazer a triagem das espécies ou ao astrônomo conceber o sistema solar: foi preciso descobrir e inventar no ardor da discussão e no calor da ação (Bastide, 1957 e Sader, 1988). Certamente, muitos conceitos ajudaram, por momentos, a recompor pedaços inteiros desse quebra-cabeça, mesmo com a perversidade da teoria do reflexo e depois do desencantamento de espelhos deformantes ou hoje quebrados. Mas, diferentemente das sociedades em que o urbano é secularizado, a cidade da América Latina não se apresenta como um objeto de inquestionável legitimidade; e, no entanto, muitas de suas megalópolis rivalizam com as nossas, e seus bairros talvez não estejam mais em crise do que em Los Angeles, East End ou Vénissieux. É provável que, enquanto não se tiver definido esta "cidade democrática" (Rodriguez, 1986), o campo da pesquisa urbana latino-americana não poderá se fechar, ou é provável que, pelo menos, continuará a ser cavalgado pelos inventores do social em busca de temas, que se territorializam cada vez mais. Do mesmo modo que a mobilidade foi o traço acentuado de país em vias de urbanização, a ancoragem em espaços 
determinados tornou-se uma necessidade imperativa para todos os que guardam a esperança de ser um dia inteiramente atores.

A palavra é dada, hoje, aos politicólogos, que pensam a cidade incontornável por quem quer analisar as diferentes formas e níveis de poder se entrecruzando nas sociedades latino-americanas: a questão da cidadania está na ordem do dia (Sachs-Jeanet, 1993). E isso não se deve apenas ao fato de que intelectuais tenham chegado a alguns postos de comando para fazer reconhecer o "direito dos cidadãos" (assim, por exemplo, o prefeito de Santo André (Daniel, 1990) ou o primeiro adjunto de Lima (Pease, 1990), ambos ardorosos pesquisadores). É também tarefa de universitários que, embora longe do político, ocupam uma posição na cena pública; tal como aquele que denuncia a perversão de relações nas quais o público é administrado como na iniciativa privada e onde o domínio particular é invadido pela norma: o que acontece então com o cidadão, bloqueado "entre a casa e a rua" (Da Matta, 1991)? É legítimo falar em "subcidadania"? E pensar que uma reconsideração da cidade possa fazer emergir uma nova urbanidade? Tais projetos são mais que puras veleidades diante de certas manifestações muito mais abruptas da urbanização, como a crescente violência ou a orfandade juvenil?

É forçoso reconhecer a importância dessas questões, no meio da crise que atinge violentamente pólos emergentes nas cidades sob o estigma de uma heterogeneidade estrutural e de uma diferenciação social redobradas (Quijano, 1989), e é forçoso igualmente admitir a ambivalência das novas formas de cidadania que surgem aí. As novas "massas urbanas" conquistaram, certamente, direitos sociais e políticos que lhes permitiriam afirmar sua autonomia, se estes não fossem negados pela constante regressão de seus direitos econômicos. Mas, tal como a classe média, as massas alcançam agora a cidade como simples citadinos, sob o jugo de um liberalismo renascendo das cinzas de projetos coletivistas abortados (Merquior, 1991). A cidadania urbana que deles resulta é um compromisso entre essas formas sociais e individuais de prática e de consciência da cidade, misturando e separando arcaísmos e modernismos numa identidade que permanece utópica porque latino-americana...

Deve-se negar que o desfecho da ação narrada assuma o aspecto de um epílogo generalizável a outras regiões? Tender-se-ia, no entanto, a pensar que a epopéia da pesquisa urbana latino-americana e as questões que ela coloca hoje, tais como a da

Rua, Campinas, 2:9-61, 1996 
cidadania, podem ser muito úteis a quem se interessa pela urbanização, fora dos cânones do Ocidente. E pontes já estão lançadas entre essa comunidade e suas correspondentes magrebinas, indianas, asiáticas, africanas ou européias, partindo de uma sensibilidade convergente, em relação aos problemas urbanos face à realidades, aos conceitos e ao posicionamento das atividades de produção de conhecimentos (Ver por exemplo Ortiz, 1991 ou Hardoy, 1989). Mas essa pesquisa concerne também a quem tem um olhar mais etnocêntrico sobre o urbano, contanto que admita o interesse de uma certa alteridade: mesmo se fenômenos como a expressão dos yuppies, dos skinheads ou dos blacks têm conotações bem diferentes aqui e lá (sem falar dos shopping centers e outros undergrounds de uma nova cultura com pretensão universal). Assim, a emergência de uma nova cidadania, projeto de civilização urbana desregionalizada, revela-se uma ambição para a aurora do século 21 .

Americanos pobres na noite da Louisiane Turistas ingleses assaltados em Copacabana Os pivetes ainda pensam que eles eram americanos Turistas espanhóis presos no aterro do flamengo Por engano Americanos ricos já não passeiam por Havana(...) E assim, ganham-se, perdem-se Concedem-se, conquistam-se direitos Enquanto aqui embaixo a indefinição é o regime E dançamos com uma graça cujo segredo nem eu mesmo sei

Entre a delícia e a desgraça Entre o mostruoso e o sublime.

(Caetano Veloso, Circuladô Vivo, 1992)

(Tradução de Consuelo Fortes Santiago e Cleonice Paes Barreto Mourão, UFMG). 


\section{BIBLIOGRAFIA}

Bastide, R. (1957) Brèsil, terre des contrastes. Paris, Hachette.

Bengoa, J. (1971) Pampa Irigoyen: lucha de clases y conciencia de clase. Santiago, CESO.

Beyer, G. (dir.). (1967) The Urban Explosion in Latin America. Ithaca, NY, Cornell University Press.

Borja, J., Calderón, F. Grossi, M. y Penalva, S. (dirs.). (1989) Descentralización y democracia. Gobiernos locales en América Latina. Santiago do Chile, CLACSOSUR-CEUMT.

Cardoso, F.-H y Faletto, E. (1969) Dependencia y desarrollo en América Latina. México, Siglo XXI. (Trad. francesa Dépendance et développement en Amérique Latine. Paris, Presses Universitaires de France, 1978).

Cardoso, R. (1983) "Movimentos sociais urbanos: balanço crítico". In B. Sorj et M. H. Tavares de Almeida (dirs.) Sociedade e Política no Brasil pós-84. São Paulo, Brasiliense.

Carrión, D. y Vainstoc, A. (dirs.) (1987) La ciudad y los ninös. Quito, Ciudad.

Castells, M. (1970) Lutes urbaines. Paris, Maspero. (Trad. espanhol Movimientos sociales urbanos. México, Siglo XIX, 1974).

CIDU (Balanowski, V. y Equipo de estudios poblacionales) (1972) "Reivindicación urbana y lucha política: los campamientos de pobladores en Santiago de Chile". Eure 2(6), pp. 55-82. (Trad. francesa em Espaces et Sociétes 6-7, 1973).

Cohen, M. (1991) Urban Policy and Economic Development. An Agenda for the 1990s. A World Bank Policy Paper. Washington, DC, Banco Mundial.

Coing, H. et Henry, E. (1989) "Pour une analyse transversale des services urbains en PED". Communication aux Journées Internationales de Lille Les villes: frein et moteur du développement du tiers-mond, 6-10 novembre 1989.

Coing, H. et Montaño, I. (1986) Le ramassage des ordures ménagères. Expériences de villes du tiers monde. Paris, Ecole Nationale des Ponts et Chaussées. 
Coraggio, J.-L. (dir.). (1990) La investigación urbana en América Latina. Caminos recorridos y por recorrer. T.3, Las ideas y su contexto. Quito, Ciudad.

Cepal (1965) El processo de industrialización en America Latina. New York, Cepal.

Cepal (1979) Estilos de desarrollo y medio ambiente en América Latina. Una interpretación global. Santiago de Chile, Cepal-Pnuma.

Da Matta, R. (1991) A casa e a rua. Espaço, cidadania, mulher e morte no Brasil. Rio de Janeiro, Guanabara Koogan.

Daniel, C. (1990) Direito à cidade. Santo André, Pinsa.

De Mattos, C. A. (1987) Paradigmas, modelos y estratégias en la práctica latinoamericana de planificación regional. Quito, Ciudad.

De Soto, H., Ghersi, E., Ghibellini, M. e Inlide (1986) El otro sendero. La revolución informal. Lima, El Barranco; Bogotá, Oveja Negra, 1987; Trad. Ing. The other Path. New York, Harper and Row, 1989.

DESAL (1966) Asi viven y asi hacen. Santiago, DESAL.

Dumas, A. (1844), Les trois mousquetaires, Paris.

Dupuy, G. (dir.). (1987) Buenos Aires: la crise des services et des infrastructures urbaines. Paris, Ècole Nationale des Ponts et Chaussées.

Duque, J. y Pastrana, E. (1971) Elementos teóricos para la interpretación de los processos reorganizativo-poblacionaes. Santiago, FLACSO.

Durand-Lasserve, A. (1986) L'éxclusion des pauvres dans les villes du tiers-monde. Accès au sol et au logement. Paris, L'Harmattan.

Feijóo, M.C. y Herzer, H.M. (dirs). (1991) Las mujeres y la vida de las ciudades. Buenos Aires, Latinoamericana.

Friedmann, J. e Salguero, M. (1987) "The Barrio Economiy and Collective Selfempowerment" in Latin America: A Framework and Agenda for Rescarch. Los Angeles, CA, School of Architecture and Urban Planning, Uela.

Galeano, E. (1971). Las venas abiertas de América Latina. Caracas.

Garza, G. \& Aguilar, S. (1989) "Medio Siglo de investigatión urbano-regionalen México”. In Carrión, F. (edit.), La investigación urbana en América Latina. Caminos recorridos y por recorrer; T. 1: Estudios nacionales. Quito, Ciudad, pp. 9-38. 
Germani, G. (1972) Consideraciones metodologicas y teóricas sobre la marginalidad en América Latina. Cambridge, MA, Harvard University Press.

Germani, G. (1962) Política y sociedad en una época de transición. Buenos Aires, Eudeba.

Gilbert, A., Hardoy, J.-E. \& Ramirez, R. (dirs). (1982) Urbanization in Contemporary Latin America: Critical Approaches of the Analysis of Urban Issues. Chichester, Wiley.

Hardoy, J.-E. (1989) Conversaciones sobre la ciudad del tercero mundo. Buenos Aires, IIED-América Latina.

Hardoy, J.-E. y Moreno, O.-A. (1974) "Tendencias y alternativas de la reforma urbana". Desarrollo Economico 13(52), pp. 627-49.

Hardoy, J.E. (dir.). (1975) Urbanization in Latin America: Approaches and Issues. New York, Anchor Press/Doubleday.

Henry, E. (1984) "La ville latino-américaine dans la sociologie". Métropolis 57, pp.4549.

Henry, E. \& Sachs, C., 1991. Evahir, conseiller et gouverner. Vingt ans de recherche urbaine latino-americaine. Paris, Inrets/Dri-Melte.

Jacobi, P. (1982). "Exclusão urbana e lutas pelo direito à moradia”, Espaço e Debates 7:53-69.

Jaramillo, S. (1985) Entre la Upac y la autoconstrucción: comentarios y sugerencias a la política de vivienda. Bogotá, Controversia/CINEP.

Jaramillo, S. (1990). "El desenvolvimiento de la discusión sobre la urbanización latinoamericana: ¿Hacia un nuevo paradigma de interpretación?” In Unda, M. (edit.), La Investigatión urbana en América Latina. Caminos recorridos y por recorrer. T. 2: Viejos y nuevos temas. Quito, Ciudad, pp. 35-74.

Lewis, O. (1961) Antropologia de la pobreza: cinco familias. México, Fondo de Cultura Econômica.

Lewis, J. (edit.) (1988). Strengthening the Poor: What Have We Learned? New Brunswick, NJ, Overseas Development Council, Transaction Books. 
Lungo Uclés, M., (1989), "La investigatión urbana en Centro América”. In Carrión, F. (edit.), La investigación urbana en América Latina. Caminos recorridos y por recorrer. T. 1: Estudios nacionales. Quito, Ciudad, pp. 39-56.

Maricato, E., (dir.). (1979) A produção capitalista da casa (e da cidade) no Brasil industrial. São Paulo, Alfa-Omega.

Merquior, J. C. (1991) O liberalismo antigo e moderno. Rio de Janeiro, Nova Fronteira.

Morse, R. (1972) "A Prolegomenon to Latin America Urban History". The American Historical Review, 52 (3), pp. 359-94.

Murmis, M. (1969) "Tipos de marginalidad y posición en el processo productivo", Revista Latinoamericana de Sociologia, 5(2), pp. 413-21.

Niedergang, M. (1972). Les vingt Amériques Latines. Paris.

Nun, J. (1969) "Sobrepoblación relativa, ejército industrial de reserva y masa marginal", Revista Latinoamericana de Sociologia, 5(2), pp.178-236.

Nunes, E. (1986). Movimientos y prácticas urbanas en Brasil". In Revista Mexicana de Sociologia, 48(4):73-86.

Perlman, J. (1976) The Myth of Marginality: Urban Povety and Policies in Rio de Janeiro. Berkeley, CA, University of California Press.

Pradilla, E. (1984) Contribución a la crítica de la 'teoria urbana'. Del 'espacio' a la 'crisis urbana'. México, UAM-Xochimilco.

Prealc (1981) Sector informal: funcionamiento y políticas. Santiago de Chile, Prealc.

Quijano, A. (1968) Notas sobre el concepto de "marginalidad social", Santiago do Chile. In Quijano, A., Imperialismo y "marginalidad" en America Latina. Lima: Mosca Azul, 1977.

Quijano, A. (1989) "La nueva heterogeneidad estructural de América Latina". In Sonntag, H. (edit.). ¿Nuevos temas, nuevos contenidos? La ciencias sociales de América Latina y el Caribe ante el nuevo siglo. Caracas, Unesco/Nueva Sociedad, pp. 29-52.

Rodriguez, A (1986) Hacia una ciudad democrática. Santiago de Chile, Sur.

Romero, J. L., 1976, Latinoamérica: las ciudades y las ideas. Mexico, Siglo XXI.

Rosembluth, G. (1963) Problemas socio-econômicos de la marginalidad y la integración urbana. Santiago do Chile, CEPAL.

Rua, Campinas, 2:9-61, 1996 
Sachs, C. (1990) São Paulo: politiques publiques et habitat populaire. Paris, Editions de la MSH.

Sachs-Jeantet, C. (1993) "La citoyenneté, projet de civilisation urbaine", à paraitre dans Homme, Ville, Nature. La culture aujourd'hui. Paris, Unesco.

Sader, E. (1988) Quando novos personagens entraram em cena. Experiências e lutas dos trabalhadores da Grande São Paulo 1970-1980. Rio de Janeiro, Paz e Terra.

Santos, M. (1982) Ensaios sobre la urbanização latino-americana. São Paulo, Hucitec.

Schteingart, M. (dir). (1989) Las ciudades latinoamericanas en la crisis. Problemas y desafios. México, Trillas.

Singer, P. (1973) Economia política da urbanização. São Paulo, Brasiliense.

Singer, P. e Brandt, V. C. (orgs.). (1980) São Paulo: o povo em movimento. Petrópolis, Vozes.

Slater, D. (ed.). (1985) New Social Movements and the State in Latin America. Amsterdam, CEDLA.

Tironi, E. (1990). Autoritarismo, modernización y marginalidad. El caso de Chile 1973 1989. Santiago do Chile, Sur.

Tockmann, V. et Klein, E. (dirs). (1979) El subempleo en América Latina. Buenos Aires, FLACSO.

Turner, J. (1963) "Dwelling Resources in South America". Architectural Design.

Urriola, R. (1988) "Crítica a una visión neoliberal del sector informal", Revista Ceplaes, 1.

Valladares, L. (1989) La recherche urbaine au Brèsil. Un état de la question. Pratiques urbaines, n. 7, Bordeaux, Interurba/CNRS-ORSTOM.

Vekemans, R. (1969) Hacia la superación de la marginalidad: algunas suggerencias. Santiago do Chile.

Vekemans, R. (1969) La marginalidad en América Latina: un ensayo de conceptualización. Santiago do Chile.

Yujnovsky, O. (1983) "Veinte años de investigación urbano-regional latino-americana", Revista Interamericana de Planificación 17(67):86-108. 